\title{
Structures and Mechanisms of 20-60-Day Intraseasonal Oscillation of the Observed Rainfall in Vietnam
}

\author{
NguYen Minh TruONG AND Bui Minh TuAN \\ Hanoi University of Science, Thanh Xuan, Hanoi, Vietnam
}

(Manuscript received 19 April 2018, in final form 4 April 2019)

\begin{abstract}
The present study explores the characteristics of the 20-60-day intraseasonal oscillation (ISO) in the 29-yr observed rainfall in north Vietnam (NVN), central Vietnam (CVN), and south Vietnam (SVN) in rainy seasons. Composite analyses reveal that the 20-60-day ISO in NVN accompanies dual vortices straddling Taiwan, which alternately favor and suppress convection extending from the northern Philippines to NVN. The wet phase in CVN coincides with convergence of northerly and easterly winds over the region. The largescale pattern governing the 20-60-day ISO in SVN resembles the characteristics of the boreal summer ISO (BSISO). Conditionally unstable anomalies are observed within anomalous anticyclones where the moisture flux diverges out during the dry phase in NVN and SVN, and vice versa. Such anomalies prevent the existence of the anticyclones and finally replace them with anomalous cyclones to start the wet phase. The unstable anomalies could result from descending motion that increases the boundary layer temperature due to adiabatic compression of air. Conversely, boundary layer cooling due to evaporation of rain and interception of solar radiation by clouds produces stable anomalies. The unstable anomalies, moisture flux convergence, and vertical motions shift northward from the convection maximum, leading to the northward propagation of the BSISO convection. The 20-60-day ISO in CVN is not governed by local instability. Vertical cross sections indicate that the ISO in SVN possesses a westward-tilting structure, which is not observed in the NVN and CVN case.
\end{abstract}

\section{Introduction}

The intraseasonal oscillation (ISO) characterized by a 20-60-day period is typically referred to as the dominant mode of intraseasonal variability of the tropics. In boreal winter, ISO is often represented by the MaddenJulian oscillation (MJO) propagating eastward along the equator (Madden and Julian 1972, 1994; Wheeler and Hendon 2004; Zhang 2005). Boreal summer ISO (BSISO) frequently originates in the western and central equatorial Indian Ocean (IO) (Yasunari 1979; Zhou and Chan 2005), and then propagates either northward in the South Asian monsoon region (Yasunari 1979, 1980; Krishnamurti and Subrahmanyam 1982; Annamalai and Sperber 2005) or eastward along the equator (Hsu et al. 2004; Li et al. 2013). Nevertheless, it might propagate northwestward in the tropical northwestern Pacific (NWP) (Kemball-Cook and Wang 2001; Teng and Wang 2003), leading to noticeable differences among

Corresponding author: Nguyen Minh Truong, truongnm@ vnu.edu.vn
ISO-active regions and seasonal dependence of ISOs (Kemball-Cook and Wang 2001; Kajikawa and Yasunari 2005; Zhang 2005). BSISO is likely more complex than MJO because of the coexistence of various low-frequency modes that might propagate in different directions and interact with each other (Kessler et al. 1995; Wang and Xie 1997; Meehl et al. 2001; Annamalai and Sperber 2005; Goswami et al. 2006).

Mechanisms often mentioned to drive ISO include surface fluxes over land, which destabilize the low-level atmosphere to the north of convection (Webster 1983), air-sea interaction (Kemball-Cook and Wang 2001; Fu et al. 2003), and internal dynamic processes of the atmosphere (Wang and Xie 1997; Jiang et al. 2004; Drbohlav and Wang 2005). Jiang et al. (2004) proposed two mechanisms governing the northward propagation of BSISO, that is, the vertical shear and moistureconvection feedback mechanism. The former couples baroclinic and barotropic modes in the free atmosphere, leading to the generation of barotropic vorticity and divergence north of the BSISO convection, which further leads to the northward shift of moisture convergence in 
TABLE 1. List of observation stations in the three climate regions of Vietnam.

\begin{tabular}{|c|c|c|c|c|c|}
\hline \multicolumn{2}{|c|}{ North } & \multicolumn{2}{|c|}{ Central } & \multicolumn{2}{|c|}{ South } \\
\hline Stations & Locations & Stations & Locations & Stations & Locations \\
\hline Ha Noi, 48820 & $21.017^{\circ} \mathrm{N}, 105.8^{\circ} \mathrm{E}$ & Tuyen Hoa & $17.883^{\circ} \mathrm{N}, 106.017^{\circ} \mathrm{E}$ & Мос Ноа, 48906 & $10.783^{\circ} \mathrm{N}, 105.933^{\circ} \mathrm{E}$ \\
\hline Hai Duong, 48827 & $20.933^{\circ} \mathrm{N}, 106.3^{\circ} \mathrm{E}$ & Dong Hoi, 48848 & $17.483^{\circ} \mathrm{N}, 106.6^{\circ} \mathrm{E}$ & Soc Trang, 48913 & $9.6^{\circ} \mathrm{N}, 105.967^{\circ} \mathrm{E}$ \\
\hline Hung Yen, 48822 & $20.65^{\circ} \mathrm{N}, 106.05^{\circ} \mathrm{E}$ & Dong Ha, 48849 & $16.85^{\circ} \mathrm{N}, 107.08^{\circ} \mathrm{E}$ & Can Tho, 48910 & $10.033^{\circ} \mathrm{N}, 105.767^{\circ} \mathrm{E}$ \\
\hline Thai Binh, 48835 & $20.45^{\circ} \mathrm{N}, 106.35^{\circ} \mathrm{E}$ & Hue, 48852 & $16.433^{\circ} \mathrm{N}, 107.583^{\circ} \mathrm{E}$ & Rach Gia, 48907 & $10^{\circ} \mathrm{N}, 105.067^{\circ} \mathrm{E}$ \\
\hline Nam Dinh, 48823 & $20.4^{\circ} \mathrm{N}, 106.15^{\circ} \mathrm{E}$ & Hoai Nhon & $14.517^{\circ} \mathrm{N}, 109.033^{\circ} \mathrm{E}$ & Ca Mau, 48914 & $9.183^{\circ} \mathrm{N}, 105.15^{\circ} \mathrm{E}$ \\
\hline Van Ly, 48829 & $20.117^{\circ} \mathrm{N}, 106.3^{\circ} \mathrm{E}$ & Quy Nhon, 48870 & $13.767^{\circ} \mathrm{N}, 109.217^{\circ} \mathrm{E}$ & Dong Phu, 48895 & $11.533^{\circ} \mathrm{N}, 106.9^{\circ} \mathrm{E}$ \\
\hline Ha Dong, 48825 & $20.967^{\circ} \mathrm{N}, 105.75^{\circ} \mathrm{E}$ & Tuy Hoa, 48873 & $13.083^{\circ} \mathrm{N}, 109.283^{\circ} \mathrm{E}$ & Vung Tau, 48903 & $10.33^{\circ} \mathrm{N}, 107.08^{\circ} \mathrm{E}$ \\
\hline Phu Lien, 48826 & $20.8^{\circ} \mathrm{N}, 106.633^{\circ} \mathrm{E}$ & Nha Trang, 48877 & $12.217^{\circ} \mathrm{N}, 109.2^{\circ} \mathrm{E}$ & My Tho, 48912 & $10.35^{\circ} \mathrm{N}, 106.4^{\circ} \mathrm{E}$ \\
\hline Bac Giang, 48809 & $21.3^{\circ} \mathrm{N}, 106.217^{\circ} \mathrm{E}$ & & & Chau Doc & $10.7^{\circ} \mathrm{N}, 105.133^{\circ} \mathrm{E}$ \\
\hline
\end{tabular}

the boundary layer. The latter is associated with moisture advection by mean flow in the boundary layer and perturbation winds. However, it is important to note that each mechanism could play a different role in the northward propagation of ISO in the IO and tropical NWP (Chou and Hsueh 2010; DeMott et al. 2013), and discrepancy more or less exists among studies on the ISO mechanisms (Jiang et al. 2004; Chou and Hsueh 2010; Kang et al. 2010; Li et al. 2013; DeMott et al. 2013).

Numerous studies have revealed that ISO is also a dominant mode in regions surrounding Vietnam. For example, Yokoi and Satomura (2005) analyzed the ISO of rainfall during the 1998 rainy season in Thailand and found that 30-60-day variations dominated during June and July, while 10-20-day variations prevailed in August and September and resembled $n=1$ equatorial Rossby (ER) waves. Mao and Chan (2005) used wavelet analyses to show how 10-20- and 30-60-day modes control the behavior of summer monsoon in the South China Sea. The former appears to be a westward-propagating anticyclone-cyclone system, while the latter exhibits a trough-ridge seesaw with an alternate occurrence of the monsoon trough and subtropical ridge over the region. The area around Bangladesh is, however, dominantly affected by submonthly scale ISO instead of 30-60-day ISO (Ohsawa et al. 2000; Fujinami et al. 2011), which modulates the total seasonal rainfall and spatial patterns of circulation and convection in summer. Fujinami et al. (2014) further indicated that the $n=1 \mathrm{ER}$ wave governs the 7-25-day ISO in the Meghalaya-Bangladesh coast of the western Myanmar region, where the ISO rainfall is strongly enhanced by local terrain of $\sim 500-\mathrm{km}$ scale.

It has been observed that Vietnam's climate could differ from that of neighboring regions in the IndoPacific domain, although they all experience the Asian monsoon (Pham et al. 2010). Furthermore, it also differs greatly among north Vietnam (NVN), central Vietnam $(\mathrm{CVN})$, and south Vietnam (SVN) because of regional interactions with specific tropical and extratropical factors (Yokoi and Matsumoto 2008; Truong et al. 2009; Yen et al. 2011; Chen et al. 2012) and the significant effect of local terrain (Nguyen-Le et al. 2014). The aforementioned ISO studies have revealed that periodicities, wavelike characteristics, and mechanisms of ISO might vary from region to region. Knowledge of regional ISOs is essential for understanding Vietnam's climate regimes and for seasonal prediction; however, their driving mechanisms have not been known. Therefore, the objective of the present study is to investigate wavelike properties and mechanisms of the ISOs in NVN, CVN, and SVN. Section 2 describes data and methods used in the present study. Large-scale seasonal mean patterns of such oscillations are described in section 3. Composites of the ISO in each region in rainy season are presented in section 4 . Sections 5 and 6 discuss the possible mechanisms and vertical structures of the ISOs. A discussion and concluding remarks are given in section 7 .

\section{Data and methods}

In the present study, daily observed rainfall was used as a primary data to detect the ISOs. Observation stations are divided into three climate regions (i.e., NVN, CVN, and SVN) based on the regionality of Vietnam's climate (Nguyen and Nguyen 2004). Table 1 gives a list of the stations and corresponding station numbers registered with the World Meteorological Organization, where we selected nine, eight, and nine stations for NVN, CVN, and SVN, respectively (Fig. 1). A period of 29 years (1981-2009) was chosen to exclude a sharp climate shift that occurred in the Pacific Ocean in 1976 (Hartmann and Wendler 2005; Meehl et al. 2009). Regional daily rainfall was first computed as the average of the daily rainfall observed at the stations within each region. It is worth noting the presence of the Truong Son Mountains in CVN. Similar to Yokoi and Satomura (2005) and Yokoi et al. (2007), power spectral density 


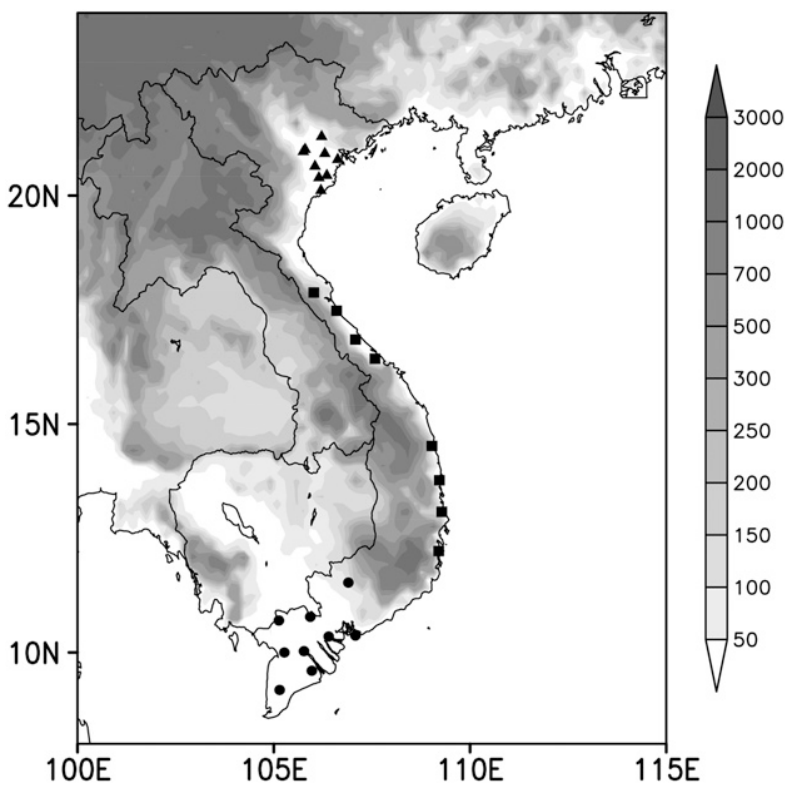

FIG. 1. Representative rain gauge stations in north (triangles), central (squares), and south (circles) Vietnam and topography (shaded in $\mathrm{m}$ MSL).

analysis applied to the regional daily rainfall exposes the existence of 10-20- and 20-60-day oscillations with 95\% statistical significance in all three regions (not shown). The former will be documented in another article, while the latter is the objective of the present study. Accordingly, the 20-60-day bandpass Lanczos filter (Duchon 1979) was applied to the regional daily rainfall and daily reanalyses of the European Centre for Medium-Range Weather Forecasts (ECMWF; Dee et al. 2011) to extract such oscillations. Reanalysis daily precipitation rate and outgoing longwave radiation (OLR) data provided by the National Oceanic and Atmospheric Administration (NOAA; Liebmann and Smith 1996) were also subjected to the filter to depict large-scale ISO rainfall and convection activities.

Regional monthly rainfall and variance of the 20-60day filtered regional rainfall anomalies in the three regions are shown in Fig. 2. It is clear that the territory cannot be considered homogeneous in terms of rainfall climatology. This inhomogeneity is basically induced by the Truong Son Mountains. For example, the Asian summer monsoon leads to hot and dry weather in CVN in summer because of the foehn effect (Nguyen-Le et al. 2014), while it produces widespread long-lasting rain in SVN. Accordingly, we defined rainy seasons that last from June to September, from September to December, and from June to October in NVN, CVN, and SVN, respectively. The annual march of the variances shows a clear seasonal variation of the filtered regional rainfall.

\section{(a) North}

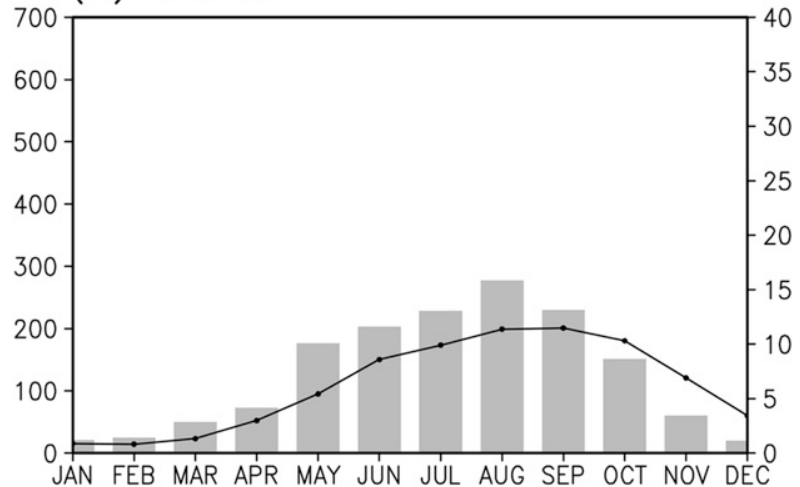

\section{(b) Central}

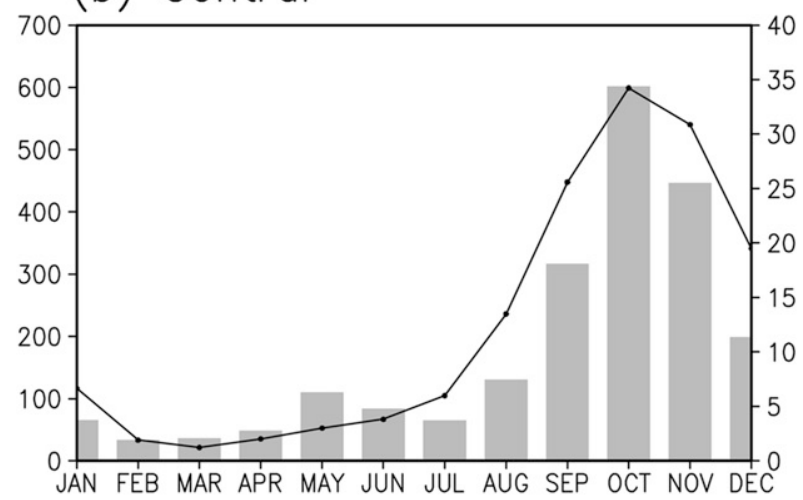

\section{(c) South}

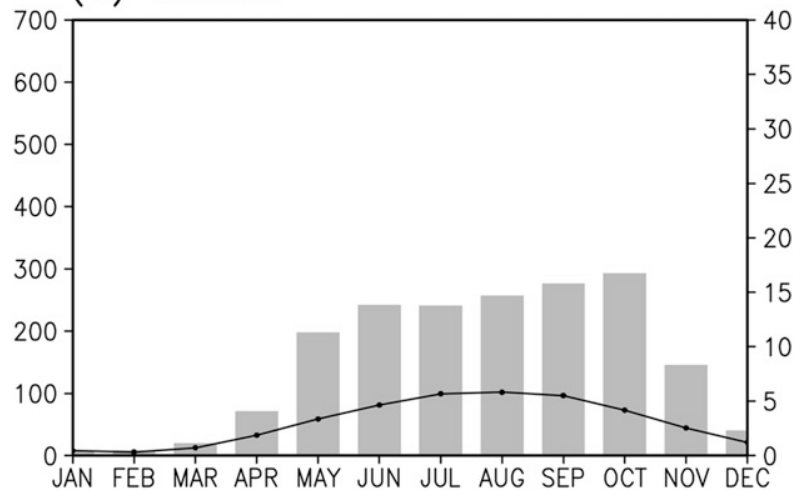

FIG. 2. Monthly observed rainfall (bars) and variance (lines) of the 20-60-day filtered regional rainfall anomalies in (a) north, (b) central, and (c) south Vietnam. The left and right ordinates indicate rainfall $(\mathrm{mm})$ and variance $\left(\mathrm{mm} \mathrm{day}^{-1}\right)$, respectively.

For NVN and SVN, the variance appears to be low in winter (November-May) but high in summer (JuneSeptember). In the CVN case, however, the seasonality is clear with high variance in fall and early winter (September-December) and low variance in spring and summer (January-August). The variance in SVN is 
smallest because the summer monsoon is the unique precipitating mechanism that evolves in a relatively stable manner over a flat terrain. Conversely, the regional daily rainfall in CVN manifests largest oscillations that could be attributed to the impact of the Truong Son Mountains on large-scale circulation.

To depict the evolution of the 20-60-day ISO largescale patterns, a compositing technique was performed for the original and derived reanalysis fields by referring to day 0 , which was determined by the days on which the regional rainfall anomalies change their sign from negative to positive (i.e., the regional rainfall changes from dry to wet phase). Their maxima (minima) occur in the middle of the wet (dry) phase. To be included in composites, a 20-60-day ISO event must consist of at least 10 consecutive dry (wet) days before (after) day 0 , and positive and negative extremes in that cycle must exceed the 29-yr climatological standard deviation. Accordingly, there are 59, 58, and 82 events detected for $\mathrm{NVN}, \mathrm{CVN}$, and SVN, respectively.

It is well known that unstable environments and/or moisture convergence are necessary conditions to trigger convection and fuel ascending motion in convective systems. In the present study, anomalies of the difference between saturation equivalent potential temperature $\theta_{e}^{*}$ at 700 and $1000 \mathrm{hPa}$ are used to represent conditional stability in the lower troposphere. Negative (positive) values indicate an unstable (stable) state of the atmosphere (Holton 2004). To show moisture convergence, vertically integrated moisture flux vector $\mathbf{Q}$ was first computed by

$$
\mathbf{Q}=\frac{1}{g} \int_{0}^{P_{s}} q \mathbf{V} d p,
$$

whose divergence is related to precipitation $P$ and evaporation $E$ in an atmospheric column by

$$
\frac{1}{g} \int_{0}^{P_{s}} \frac{\partial q}{\partial t} d p+\operatorname{div} \mathbf{Q}=E-P .
$$

For a long period, one may have the hydrological relationship

$$
\operatorname{div} \mathbf{Q}=E-P,
$$

which suggests that $\operatorname{div} \mathbf{Q}$ should be a major moisture source of clouds and precipitation (Sohn et al. 2004; Banacos and Schultz 2005), which, in turn, govern circulation and instability in the lower troposphere as mentioned later in the last sections. Here $g$ is the acceleration of gravity, $q$ is specific humidity, $\mathbf{V}$ is the horizontal wind vector, and $P_{s}$ is the surface pressure. Therefore, the divergent component of anomalous moisture flux (AMF) was then taken into account in association with anomalous reanalysis rainfall (ARR).

\section{Seasonal mean patterns}

This section provides a brief description of background environments of 20-60-day ISO events detected in the rainy seasons in the three climate regions of Vietnam. Specifically, the 20-60-day ISO in the observed rainfall in NVN happens in a large-scale seasonal mean pattern where the NWP subtropical high (NWPSH) is present and extends to $\sim 130^{\circ} \mathrm{E}$, whose axis can be found at $\sim 30^{\circ}-35^{\circ} \mathrm{N}$ in the southwest-northeast direction (Fig. 3a). A low-level jet is present off the Somali coast over the Arabian Sea (AS) while monsoon westerlies blow across south India, the Bay of Bengal $(\mathrm{BoB})$, and the southern Indochina Peninsula to $120^{\circ} \mathrm{E}$. These flows are presumed to hold a lot of moisture and, therefore, favor wavelike disturbances in the tropical Asian region (Fukutomi and Yasunari 2002; Fujinami et al. 2014). In the Southern Hemisphere, easterly trade winds diverge from the northern flank of the Mascarene and Australian high and then curve northward at the equator because of the Coriolis effect, to create the lowlevel jet and monsoon westerlies.

In the case of CVN, the seasonal mean 850-hPa largescale pattern is characterized by an extratropical trough that emerges over northeast Asia and pushes the weakening NWPSH southward (Meehl et al. 2001), which is zonally elongated as usually seen in winter when the Somali low-level jet and monsoon westerlies vanish over the AS and BoB (Fig. 3c). Trade winds prevail in the tropical NWP and blow toward Vietnam. The corresponding pattern of the SVN case is similar to that of the NVN case, except that both the NWPSH and northeast Asian trough are slightly stronger (Fig. 3e). However, characteristics of the 20-60-day ISOs in both regions are different as discussed later. The 200-hPa wind fields (Figs. 3b,d,f) suggest that vertical shear of the horizontal winds is larger in the tropical IO than in the tropical NWP. Specific humidity is, however, greater in the latter ocean. To focus on significant signals, anomalies plotted in composite figures in the next sections are $95 \%$ statistically significant based on the Student's $t$ test.

\section{Composite analyses}

\section{a. NVN: Stationary wave structure}

Composites of the 20-60-day filtered ARR and 850$\mathrm{hPa}$ wind anomalies corresponding to the observed rainfall ISO in NVN are illustrated in Fig. 4. At the beginning of the dry phase, there is almost no rainfall 
(a) North: $850-\mathrm{hPa} u, v$

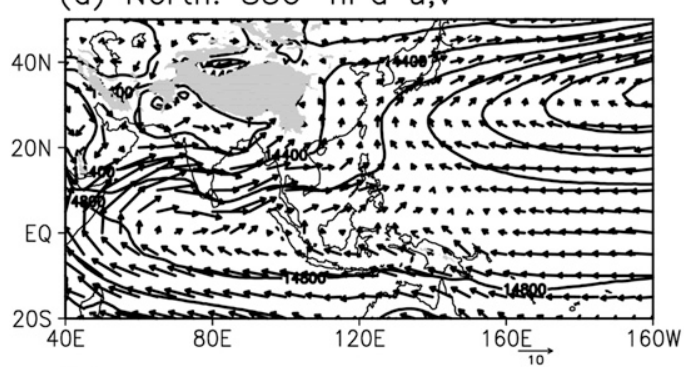

(c) Central: $850-\mathrm{hPa} u, v$

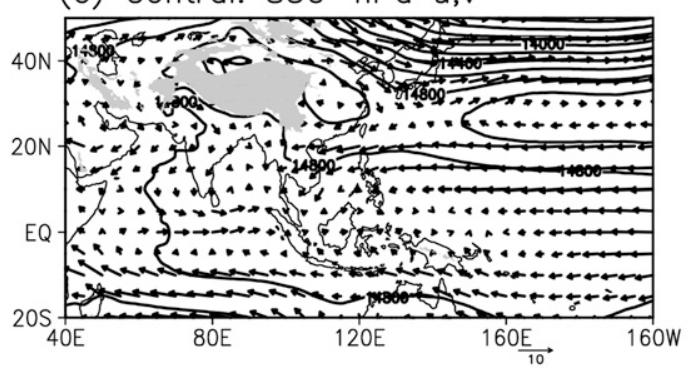

(e) South: $850-h P a ~ u, v$

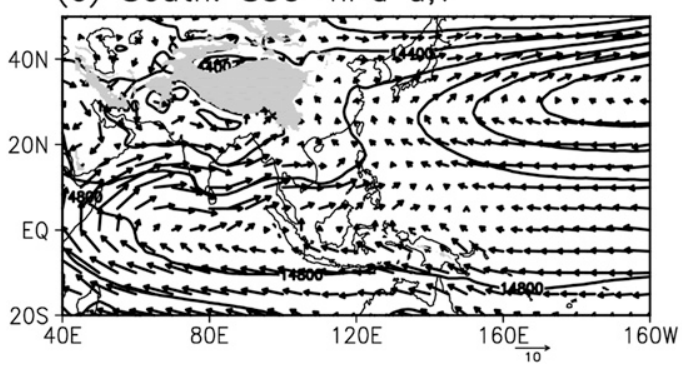

(b) North: 200-hPa u,v

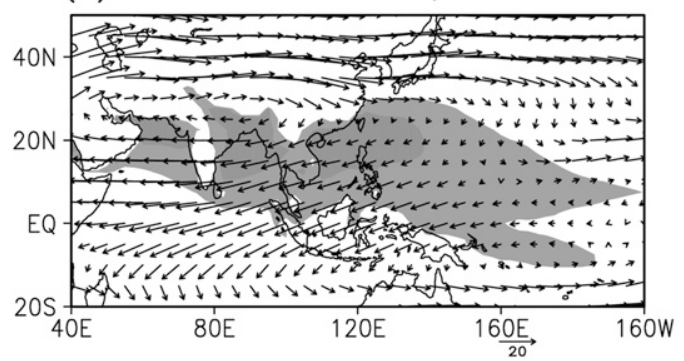

(d) Central: 200-hPa u,v

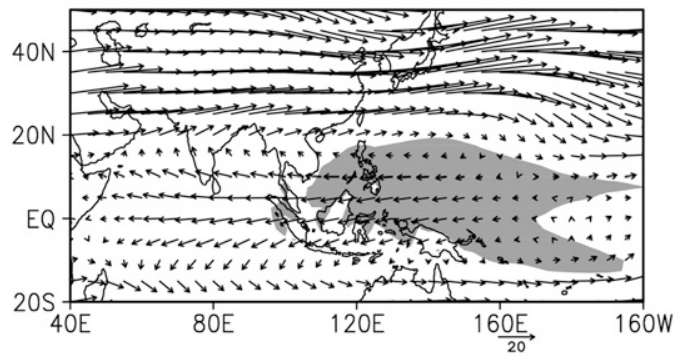

(f) South: 200-hPa u,v

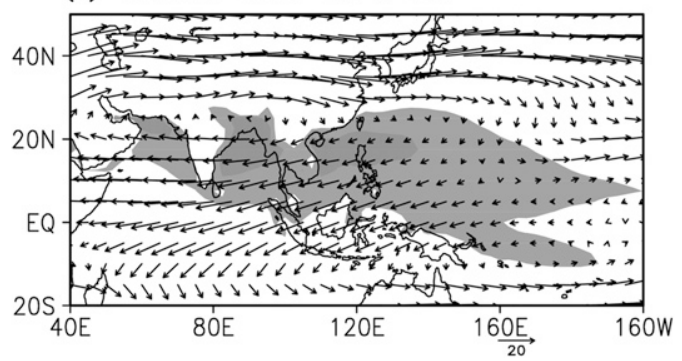

FIG. 3. Background fields of the 20-60-day ISO in the rainy season in (a),(b) north, (c),(d) central, and (e),(f) south Vietnam. Shown are (left) 850-hPa winds (vectors; $\mathrm{m} \mathrm{s}^{-1}$ ), geopotential height (contours; gpm), and topography (shading), and (right) $200-\mathrm{hPa}$ winds (vectors; $\mathrm{m} \mathrm{s}^{-1}$ ) and $1000-\mathrm{hPa}$ specific humidity greater than $17 \mathrm{~g} \mathrm{~kg}^{-1}$ (shading).

signal in the entire domain. Wind anomalies are calm, except anomalous easterly winds along $\sim 40^{\circ} \mathrm{N}$ in the NWP and weak anomalous northerly winds over northeast China and Mongolia (Fig. 4a). However, circulation and rainfall anomalies evolve very quickly as the dry phase matures by day -10 . Specifically, the anomalous northerly winds inundate the eastern part of China and favor a cyclonic anomaly to grow and extend southward over the East China Sea and the southern part of Japan (Figs. 4b,c). At the same time, an anticyclonic anomaly develops rapidly to the southwest of the cyclone, creating dual vortices symmetric about Taiwan. Anomalous easterly winds begin to dominate from the Indochina Peninsula to India, and anomalous southerly winds cross the equator along $\sim 105^{\circ} \mathrm{E}$. Anomalous westerly winds along $\sim 17^{\circ} \mathrm{N}$ in the NWP perhaps imply a weakening of the trade winds. In accordance with the dual vortices, a positive ARR can be seen southwest of Japan, and notably, a strong negative ARR covers the northern Philippines-NVN region, indicating deficient rainfall.

The large-scale ISO pattern at day 0 appears to possess structures that are opposite to those at day -15 , giving the signal of the wet phase. That is, anomalous southerly winds are found over northeast China and the $\mathrm{BoB}$, while a cyclonic anomaly is growing east of Japan in the NWP (Fig. 4d). The entire pattern evolves rapidly around day +5 when the regional rainfall anomalies are maximum. It is noteworthy that anomalous winds are organized in a stationary wave structure extending from the central IO in the Southern Hemisphere to the western North Pacific. Vorticity and rainfall anomalies are again symmetric about Taiwan, but their signs are reversed (Fig. 4e). The negative ARR is replaced by a robust positive anomaly covering the northern Philippines-NVN region, which brings the wet phase to NVN and is confined by a cyclonic anomaly. Rainfall deficits occur within an anticyclonic anomaly over the 
(a) North: Day -15

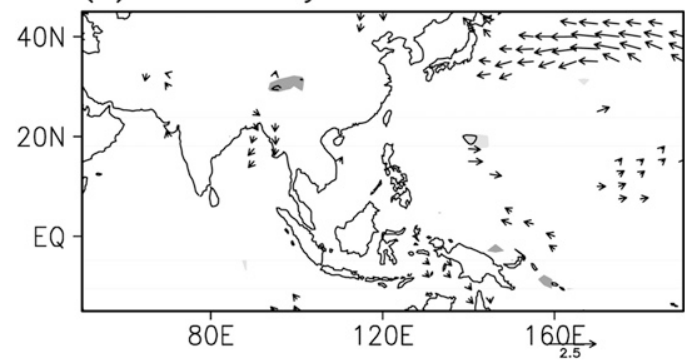

(c) North: Day -5

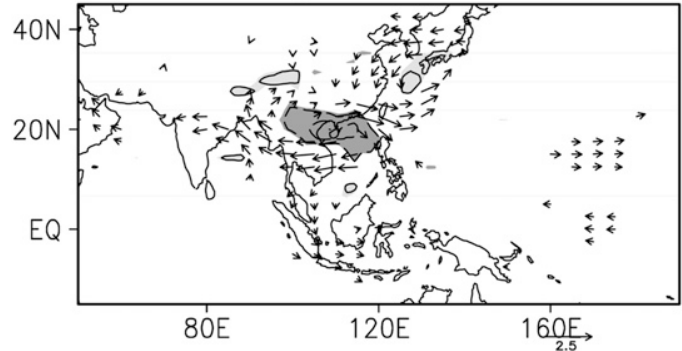

(e) North: Day 5

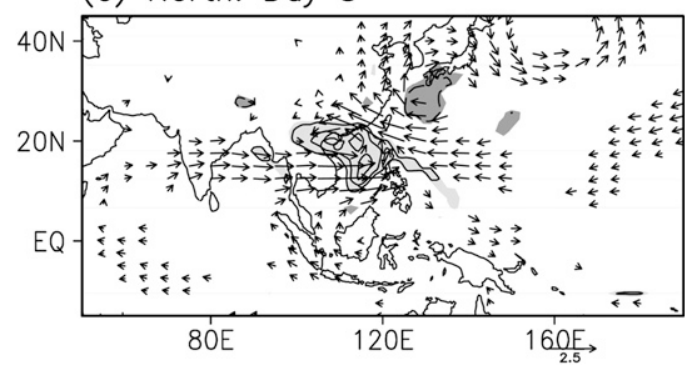

(b) North: Day -10

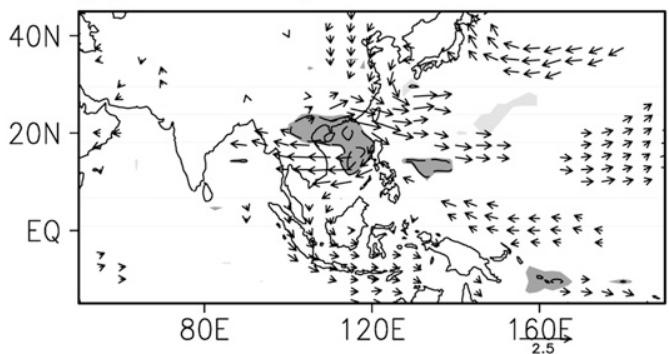

(d) North: Day 0

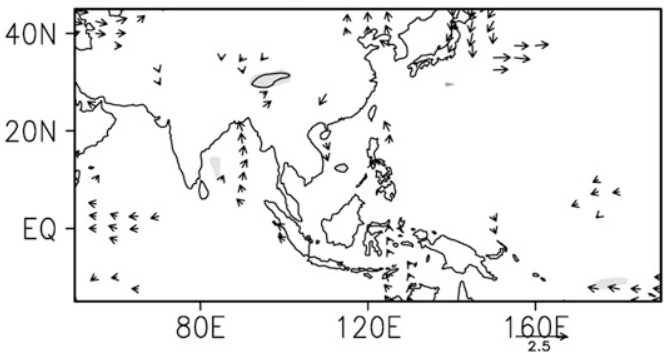

(f) North: Day 10

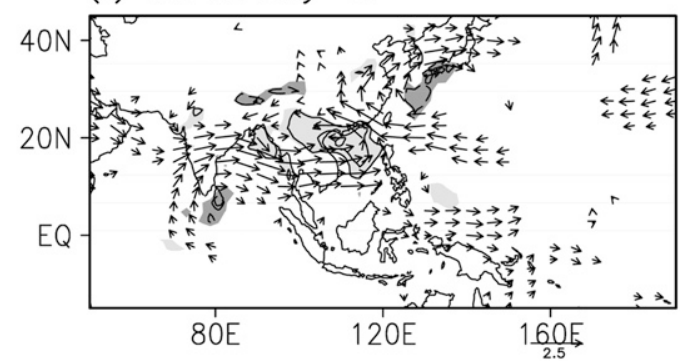

FIG. 4. Composites of the 850-hPa wind vector $\left(\mathrm{m} \mathrm{s}^{-1}\right.$ ) and ARR anomalies (contours) associated with the 20-60day ISO in north Vietnam. Solid (dashed) contours indicate positive (negative) values shaded by light (dark) gray. Contour interval is $1 \mathrm{~kg} \mathrm{~m}^{-2}$ day $^{-1}$. Only $95 \%$ statistically significant anomalies are plotted.

East China Sea, while anomalous westerly winds rapidly extend from the AS to the Philippines, which are probably the South Asian summer monsoon flow. For the composite at day +10 , the cyclone nearly disappears east of Japan, while the anticyclone expands in the NWP and anomalous easterly winds to its south are likely the trade winds (Fig. 4f). As mentioned in Fukutomi and Yasunari (2002), the Philippines can be considered a source of wavelike disturbances in the tropical NWP. As time elapses, the anomalies are damped out until ARR becomes neutral again over NVN at day +15 (not shown), presenting a pattern similar to that at day -15 and ending the ISO cycle.

\section{b. CVN: Southward intrusion of anomalous northerly winds}

The dry phase of the 20-60-day ISO in CVN starts with nearly insignificant circulation and rainfall anomalies in the whole domain, except weak anomalous southerly winds over northeast China (Fig. 5a). In the second composite, two branches of anomalous southerly winds can be observed to suddenly blow over the eastern part of China and adjacent seas, which appear to originate from South and Southeast Asia in the form of anomalous westerly winds traversing the Indochina Peninsula and Philippines to the NWP. This circulation produces a divergence pattern associated with an anticyclonic anomaly located between the Philippines and Vietnam, where rainfall is expected to be abnormally deficient. Anomalous westerly winds in the NWP may suggest a slight weakening of the NWPSH (Fig. 5b). The negative ARR expands westward to the eastern BoB and reaches the minimum value by day -5 , when the anomalous southerly winds begin withdrawing to the south of $35^{\circ} \mathrm{N}$, but anomalous easterly winds are formed across the tropical IO to enhance divergence over the region (Fig. 5c).

Although the negative ARR is still present over the eastern $\mathrm{BoB}$ and the anomalous easterly winds still 
(a) Central: Day -15

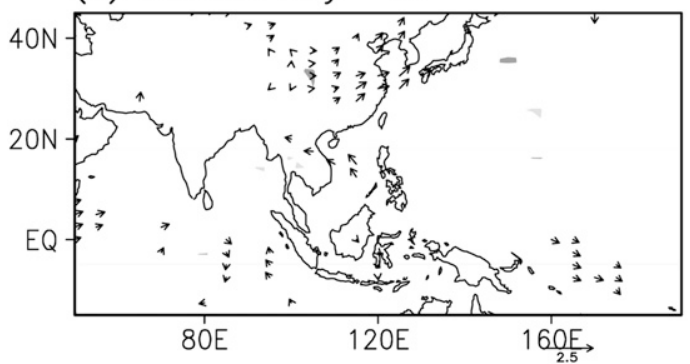

(c) Central: Day -5

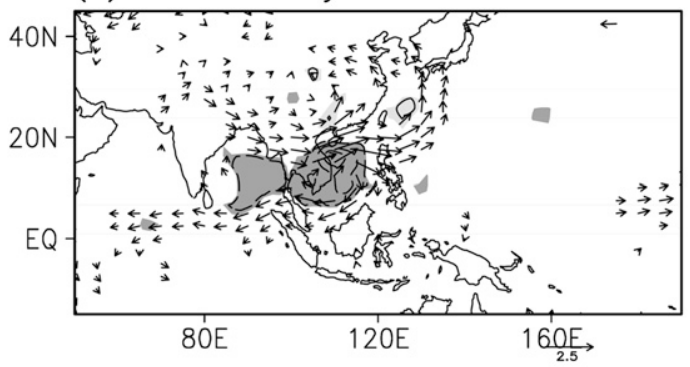

(e) Central: Day 5

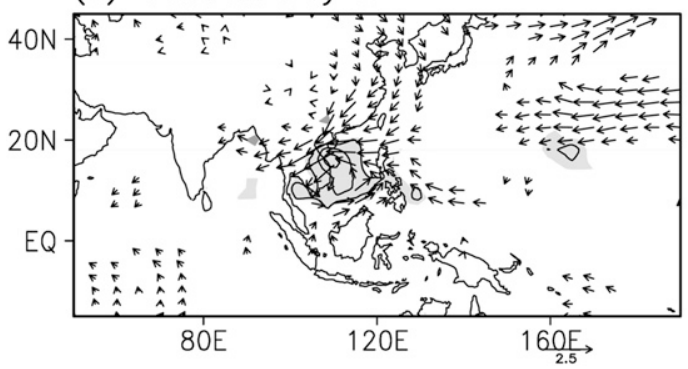

(b) Central: Day -10

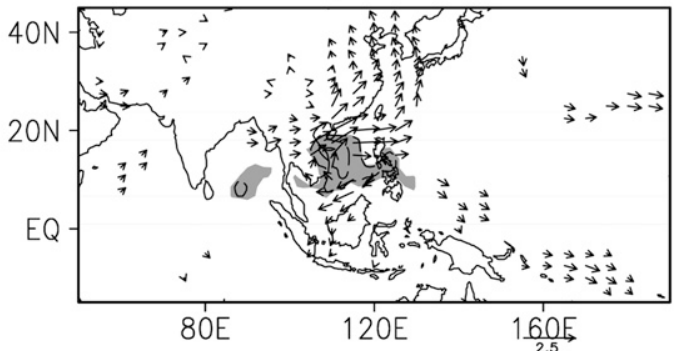

(d) Central: Day 0

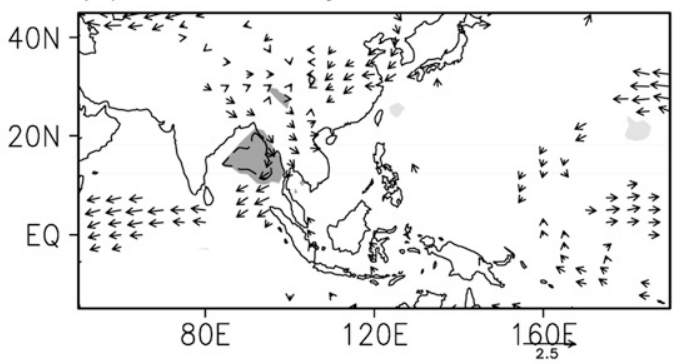

(f) Central: Day 10

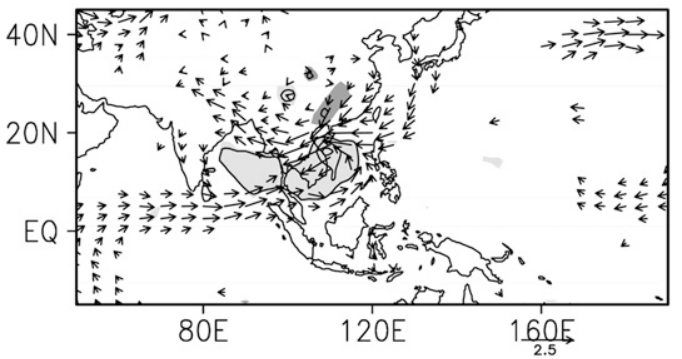

FIG. 5. As in Fig. 4, but for central Vietnam.

exist in the tropical IO, rainfall deficit disappears over mainland Southeast Asia and adjacent seas and anomalous northerly winds begin to develop over northeast Asia, implying changes from the dry to wet phase in CVN at day 0 (Fig. 5d). In a manner opposite to that in the dry phase, circulation anomalies develop very quickly with the anomalous northerly winds prevailing over the eastern part of China and adjacent seas and anomalous easterly winds extending from east of the Philippines to the northern BoB (Fig. 5e). Therefore, convergence replaces divergence and a positive ARR is clearly present within a cyclonic anomaly centered off the CVN coast. The NWPSH is expected to be intensified as a remarkable anticyclonic circulation occurs in the NWP. Although the anomalous northerly winds vanish north of $35^{\circ} \mathrm{N}$, the positive ARR not only remains stationary off the CVN coast but also expands to the central $\mathrm{BoB}$ with the help of anomalous westerly winds extending from Somalia to the Malay Peninsula, and thereby maintaining convergence over the region (Fig. 5f).
ARR becomes neutral again over $\mathrm{CVN}$ at day 15 (not shown).

\section{c. SVN: BSISO structure}

Figure 6 shows large-scale composites of rainfall and 850-hPa wind anomalies associated with the 20-60-day ISO in the observed rainfall in SVN. Beginning at day -15 , several negative ARR anomalies are detected in the tropical NWP and over the AS, whose horizontal scales are small (Fig. 6a). However, these anomalies grow and merge with each other to form a vigorous belt of rainfall deficiency at $\sim 60^{\circ}-155^{\circ} \mathrm{E}$ in the second composite. On both sides of this belt, anomalous westerly winds extend from South Asia to the NWP, whereas anomalous easterly winds abruptly prevail from the NWP to the AS along $\sim 10^{\circ} \mathrm{N}$ that then curve northeastward to the equatorial IO (Fig. 6b). Such anomalous winds probably imply a weakening of both the South Asian summer monsoon and the trade winds in the NWP, but favor an anticyclonic anomaly over the Philippines and surrounding areas. The dry 
(a) South: Day -15

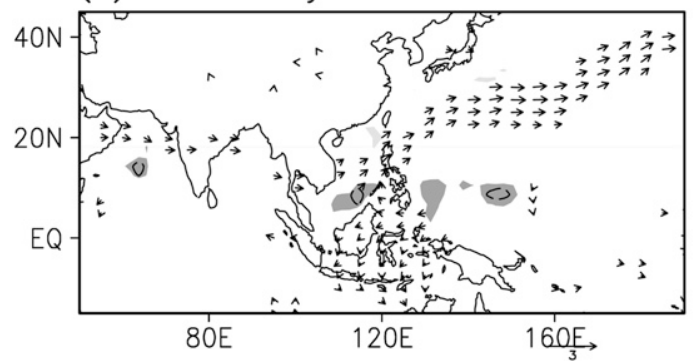

(c) South: Day -5

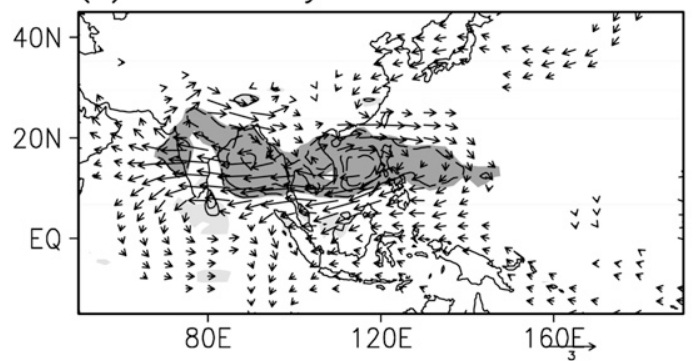

(e) South: Day 5

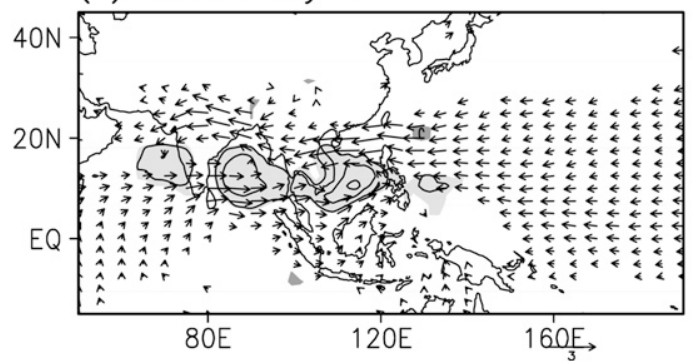

(b) South: Day -10

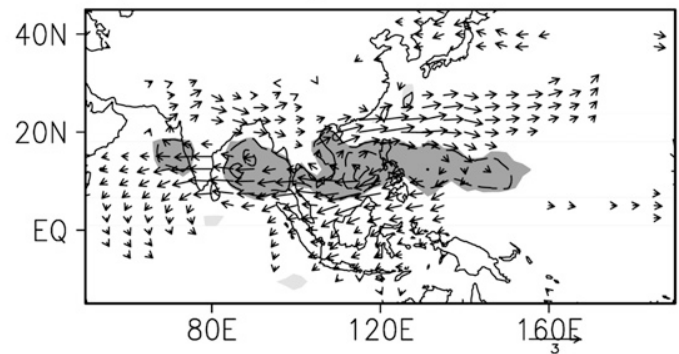

(d) South: Day 0

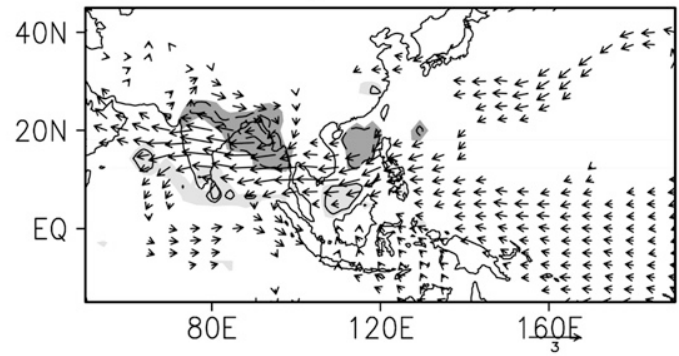

(f) South: Day 10

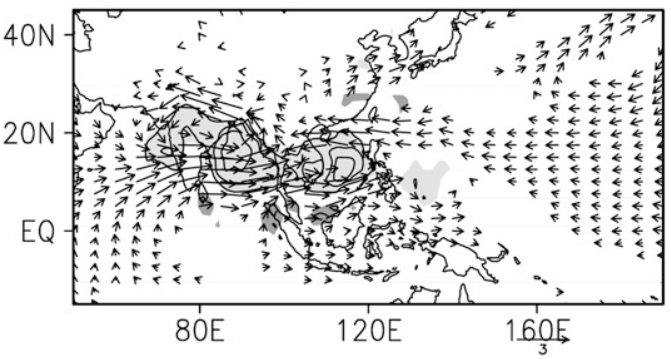

FIG. 6. As in Fig. 4, but for south Vietnam.

phase in SVN is subsequently characterized by a slow northward propagation of the negative ARR anomalies in association with the intensification and westward expansion of the anomalous easterly winds along $10^{\circ}-15^{\circ} \mathrm{N}$ toward the Arabian Peninsula, while two rainfall signals originate in the tropical IO and northwest of Borneo, develop, and propagate northward (Figs. 6b-d).

The wet phase in SVN is finally triggered by the northward propagation and zonal expansion of the positive ARR anomalies in the tropical NWP and IO after day 0 (Figs. 6d,e), while the negative ARR anomalies decay and anomalous easterly winds progress in the equatorial NWP. It is also important to note that anomalous westerly winds, which originate from the Southern Hemisphere, develop quickly across the tropical IO and Maritime Continent to the tropical NWP (Fig. 6e); meanwhile the anomalous easterly winds inundate the tropical NWP and extend westward to north India along $\sim 23^{\circ} \mathrm{N}$. In contrast to the dry phase, these anomalous winds may suggest an outbreak of both the South Asian summer monsoon and the trade winds in the NWP. Accordingly, the belt of excessive rainfall becomes well organized in the northwest-southeast direction at $\sim 60^{\circ}-140^{\circ} \mathrm{E}$ while propagating northward. The anomalous easterly winds begin weakening in the tropical NWP at day +10 , when the anomalous westerly winds continuously strengthen in the tropical IO and propagate northward, leading to a farther northward propagation of the positive ARR belt. It is worth noting that newly formed negative ARR anomalies are situated exactly over the previous positive anomalies in the tropical NWP and IO (Fig. 6f), which are expected to propagate northward later to initiate a new dry phase in SVN. The above large-scale patterns, anomalies, and propagation directions resemble those of BSISO described in previous studies (Chou and Hsueh 2010; Kikuchi et al. 2012; DeMott et al. 2013). The ISO cycle is ended with a neutral ARR anomaly over SVN at day +15 (not shown), during which no significant rainfall signal is found over NVN (also refer to DeMott et al. 2013). 
(a) North: Day -10

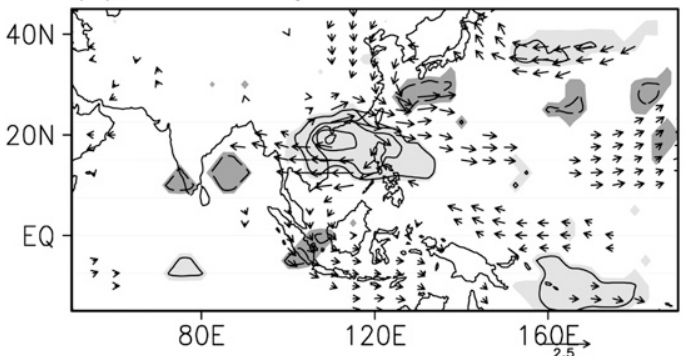

(c) Central: Day -10

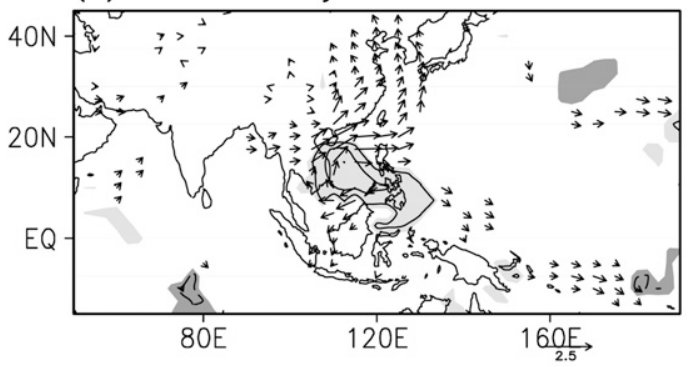

(e) South: Day -10

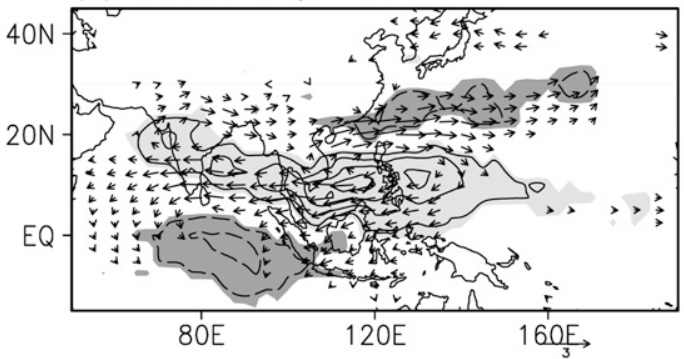

(b) North: Day 10

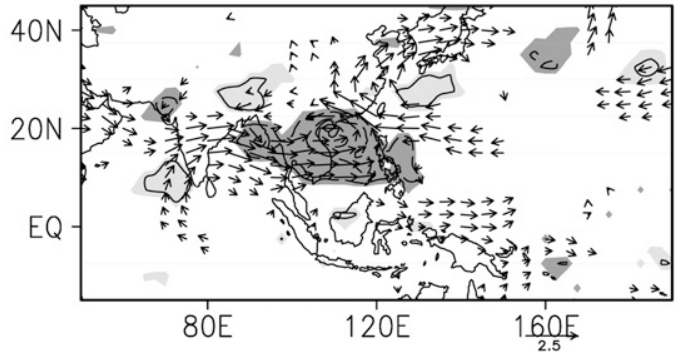

(d) Central: Day 10

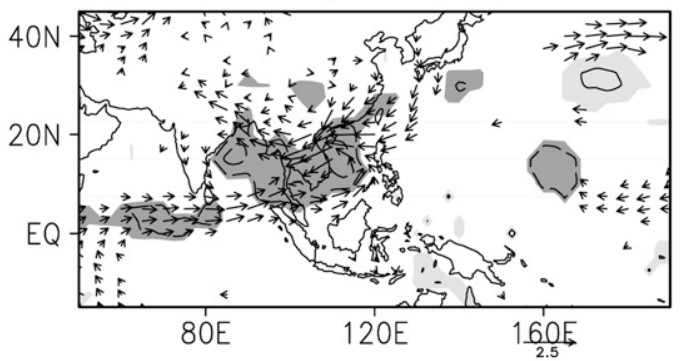

(f) South: Day 10

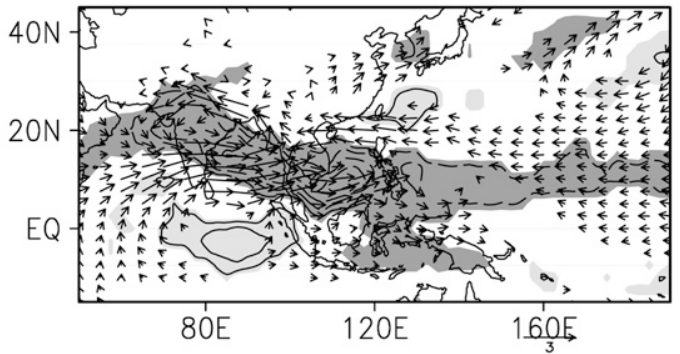

FIG. 7. OLR (contours) and 850-hPa wind vector anomalies $\left(\mathrm{m} \mathrm{s}^{-1}\right)$ at day (left) -10 and (right) +10 associated with the 20-60-day ISO in (a),(b) north, (c),(d) central, and (e),(f) south Vietnam. Solid (dashed) contours indicate positive (negative) values shaded by light (dark) gray. Contour interval is $4 \mathrm{~W} \mathrm{~m}^{-2}$. Only $95 \%$ statistically significant anomalies are plotted.

\section{d. Convection activities}

Figure 7 illustrates the horizontal distribution of anomalous OLR associated with the 20-60-day ISOs in the three regions, which can serve as a proxy for largescale convection activities. As expected, convection is suppressed (i.e., positive anomalous OLR) in the dry phase and vice versa. The anomalous OLR field attains its maximum after day -10 (Figs. 7a,c,e) and minimum at about day +5 (not shown) before slightly increasing again until day +10 (Figs. 7b,d,f). Such an oscillation evolves nearly $180^{\circ}$ out of phase with the oscillation in the ARR field given above. These two fields coincide in space but the former is significant in a broader horizontal scale, especially in the SVN case. This suggests that large-scale tropical convection may essentially control the ISOs in the observed rainfall in Vietnam. Note that a positive (negative) OLR anomaly originates in the equatorial IO, extends zonally while propagating northward, and then triggers the dry (wet) phase in SVN in the form of the BSISO structure (Figs. 7e,f) as mentioned previously.

\section{Possible mechanisms of the regional rainfall ISOs}

\section{a. Conditional stability and moisture flux}

In accordance with the ARR and circulation anomalies mentioned previously, anomalous stability and moisture flux are insignificant at the beginning of the dry phase in NVN (Fig. 8a). However, divergence of AMF evolves and rapidly matures over a vast region of the Indochina Peninsula, Philippines, and South China by day -10 , when an unstable anomaly is seen in the east quadrant of the divergent area and a smaller stable anomaly can be found in the opposite quadrant over land (Fig. 8b). Physically, the unstable lower troposphere 
(a) North: Day -15

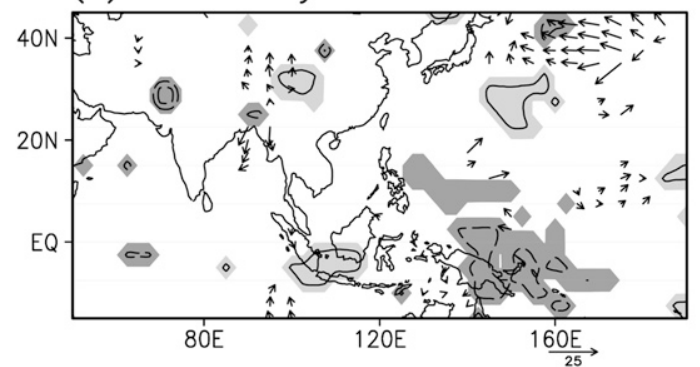

(c) North: Day -5

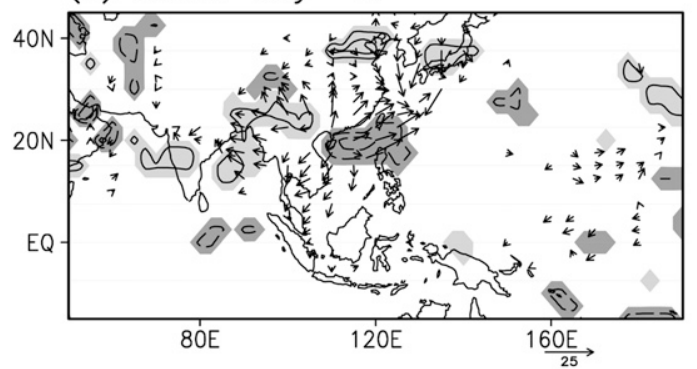

(e) North: Day 5

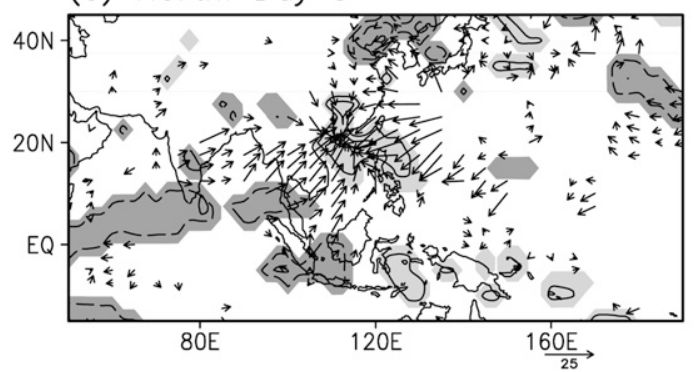

(b) North: Day -10

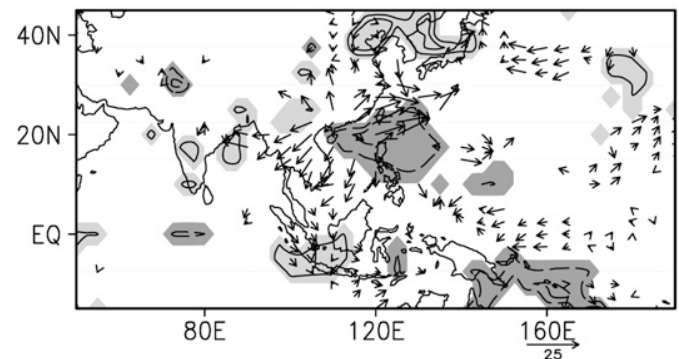

(d) North: Day 0

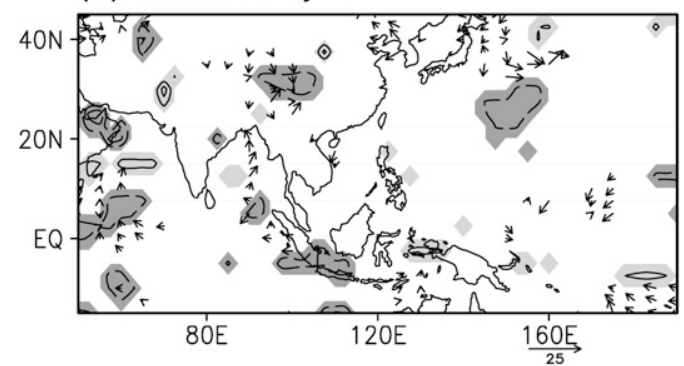

(f) North: Day 10

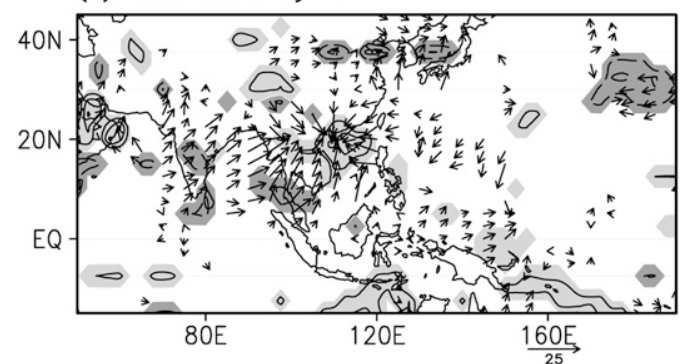

FIG. 8. Composites of the divergent component of anomalous moisture flux (vectors; $\mathrm{kg} \mathrm{m}^{-1} \mathrm{~s}^{-1}$ ) and 700-1000$\mathrm{hPa} \theta_{e}^{*}$ difference anomalies (contours) associated with the 20-60-day ISO in north Vietnam. Solid (dashed) contours indicate positive (negative) values shaded by light (dark) gray. Contour interval is $0.9 \mathrm{~K}$. Only $95 \%$ statistically significant anomalies are plotted.

imposes unfavorable conditions for development, or suppresses the anticyclone southwest of Taiwan. The stable anomaly continues its development, whereas the unstable anomaly and AMF divergence slightly weaken (Fig. 8c), even though the lower troposphere remains nearly neutral over NVN during the dry phase. Anomalous instability and moisture flux are insignificant again over the Philippines-Vietnam region at day 0 , suggesting a transition state to the wet phase (Fig. 8d). The divergence is then replaced by a strong convergence of AMF from the equatorial and tropical NWP and the BoB (Fig. 8e), which is in turn presumed to favor ascending motion and thereby contributes to the reverse of the circulation anomalies not only over NVN, but also over the BoB and AS (Figs. 4e,f). Note that the AMF convergence is expected to produce clouds and precipitation (Sohn et al. 2004), which brings the wet phase to NVN and results in a stable anomaly that is newly formed and expands westward over the region (Figs. 8e,f), leading to the decay of the cyclone southwest of Taiwan, which requires an unstable environment. Compared to the OLR and ARR fields, it is found that the stability lags behind the signal in these fields.

In the first composite of the CVN case, the lower troposphere is slightly stable over the Indochina Peninsula, whereas it appears to be unstable over South China and East Asia. However, AMF has almost no physical meaning in the entire domain (Fig. 9a). The unstable area then expands and spreads southward to cover the Philippines-Vietnam region and South China, where a divergence of AMF evolves very quickly (Fig. 9b). It can be seen that the positive OLR anomaly (Fig. 7c) accompanies the AMF divergence off the CVN coast and over the Philippines that matures at day -5 . Following the propagation and weakening of the unstable air, a vast area of stable air develops along the 
(a) Central: Day -15

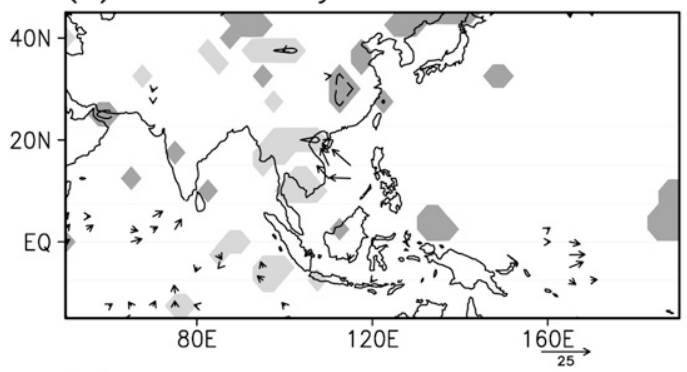

(c) Central: Day -5

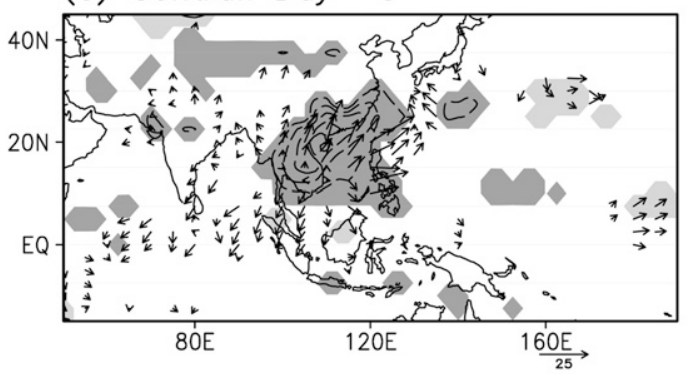

(e) Central: Day 5

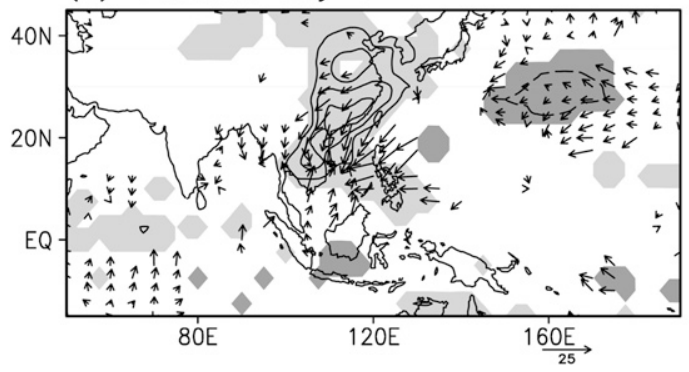

(b) Central: Day -10

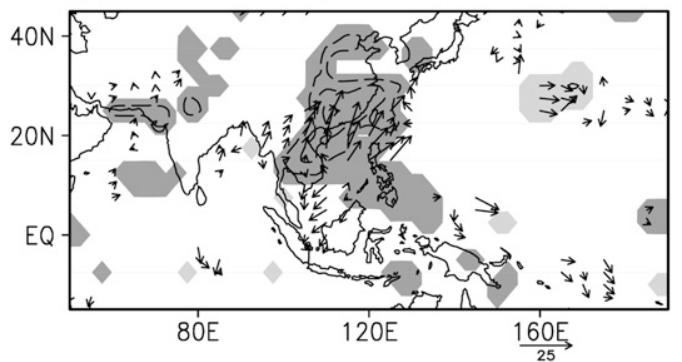

(d) Central: Day 0

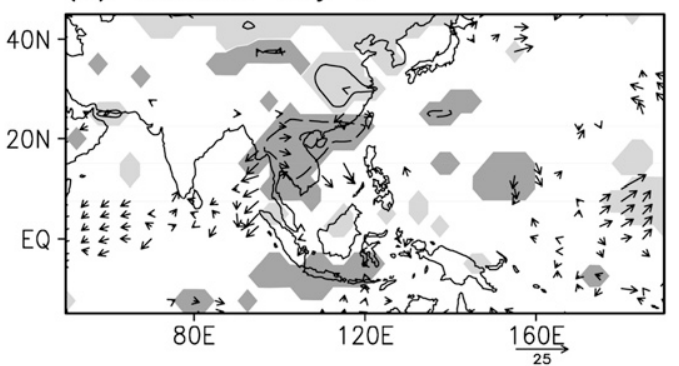

(f) Central: Day 10

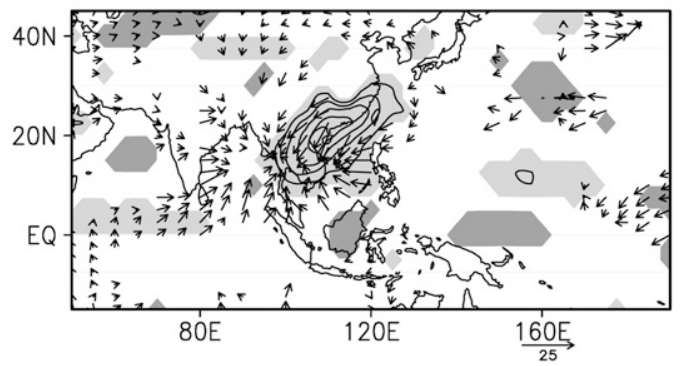

FIG. 9. As in Fig. 8, but for central Vietnam. Contour interval is $1.35 \mathrm{~K}$.

northern-eastern rim of the Tibetan Plateau and then intrudes southward to Vietnam (Figs. 9c-f), which is in turn followed by a newly formed unstable anomaly at day +10 (Fig. 9f). The track of the stable anomaly is similar to that of anomalous cold air described by Pan et al. (2013). The wet phase is actually a reversal in structure of the dry phase, that is, the lower troposphere becomes stable and a vigorous convergence of AMF is observed over $\mathrm{CVN}$ and neighboring regions in the form of a narrow zonal belt. It is, therefore, clear that the ISO rainfall in CVN is solely induced by the AMF convergence rather than unstable environment, and the aforementioned negative OLR anomalies (Fig. 7d) result from forced convective clouds that form under conditions of large-scale moisture convergence.

For the SVN case, it can be seen that the positive OLR anomalies are basically associated with unstable anomalies and vice versa during the northward and eastward propagation of the 20-60-day ISO (Figs. 7 and 10). At the beginning of the dry phase, the lower troposphere is neutral over mainland Southeast Asia, but unstable in the equatorial NWP and over the AS-BoB region (Fig. 10a). A stable anomaly develops in the equatorial IO at day -10 when the unstable anomaly propagates northward in the tropical NWP and expands westward to cover SVN (Fig. 10b). It is noteworthy that 1) compared to Fig. 7e, these anomalies are located a few degrees of latitude north of the OLR anomalies, 2) AMF vigorously diverges out from the unstable anomalies in the tropical NWP and BoB, from where northerly AMF is likely to become the sole moisture supply for convection in the tropical $\mathrm{IO}$, and 3) the northerly AMF appears to be blocked by a narrow band of maximum stable anomalies in the tropical IO (Figs. 10b,c). Jiang et al. (2004) hypothesized that moisture convergence should be induced by anomalous northerly winds to the north and anomalous southerly winds to the south of the convection center. Here we see, however, that a convergence of the northerly AMF is enough to fuel convection in the tropical IO. As time advances the stable 
(a) South: Day -15

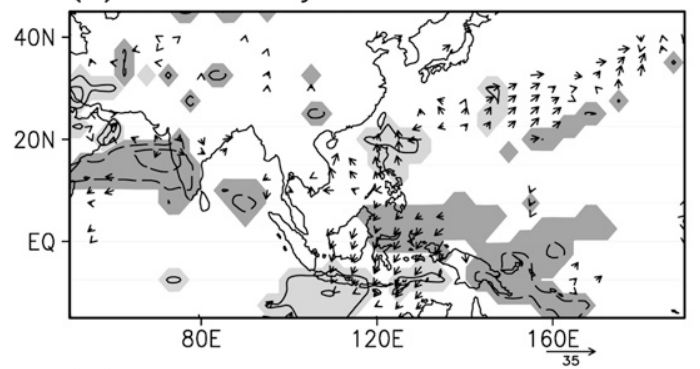

(c) South: Day -5

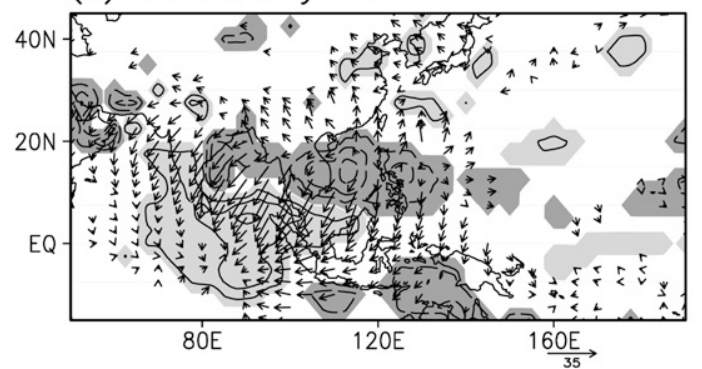

(e) South: Day 5

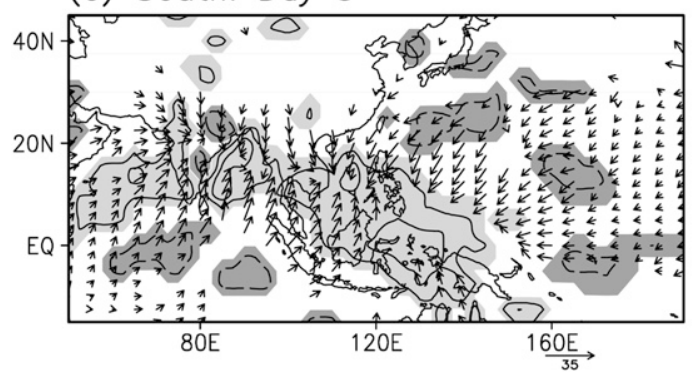

(b) South: Day -10

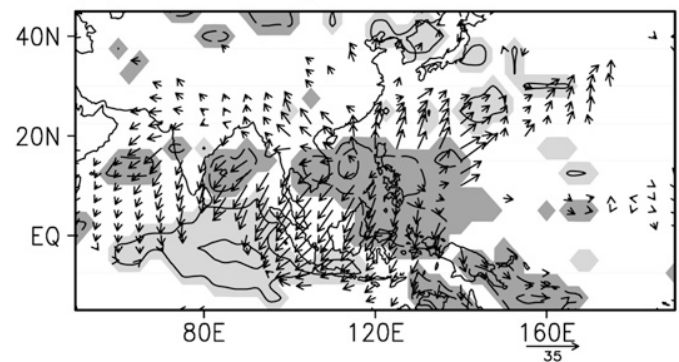

(d) South: Day 0

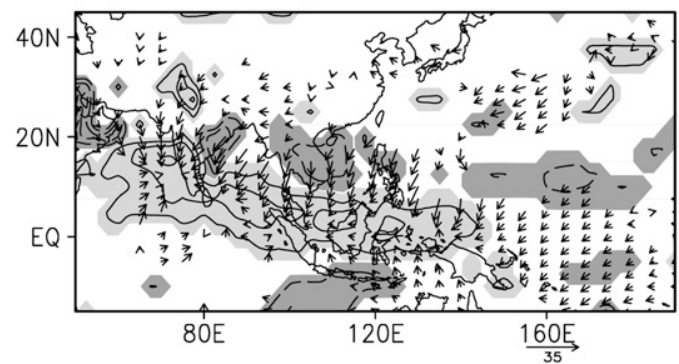

(f) South: Day 10

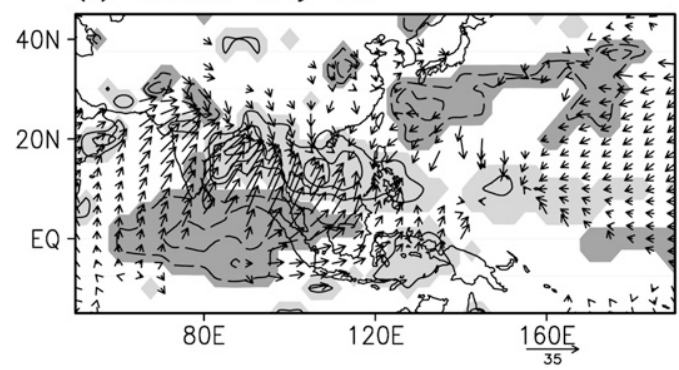

FIG. 10. As in Fig. 8, but for south Vietnam.

anomaly propagates northward and eastward to the tropical NWP, while the unstable anomalies and northerly AMF weaken (Fig. 10d). In an opposite manner, an unstable anomaly evolves in the equatorial IO in the wet phase, from where southerly AMF diverges out and gradually becomes a major moisture supply for convection in the tropical NWP and BoB that continues propagating northward (Figs. 10e,f). It is interesting to note the presence of northerly AMF in the Asia-Pacific region that helps create a band of AMF convergence along a band of maximum stable anomalies in the tropical NWP and BoB (i.e., a few degrees of latitude north of the convection maximum). Compared with the ARR and OLR signal, the stability also appears lagged in the SVN case.

\section{b. Vertical motions, temperature, and humidity}

It is indicated in section $5 \mathrm{a}$ that unstable anomalies might also be formed over the tropical oceans where the underlying water layer has a larger heat capacity than the soil layer in mainland Asia. Therefore, there may have been different mechanisms that could lead to the formation of conditional instability as mentioned previously.

Our composite analyses reveal that 850 -hPa vertical motions develop almost in phase and coincide spatially with the OLR field (Figs. 7 and 11; i.e., out of phase with the ARR field). Descending motion prevails where the positive OLR anomalies occur (e.g., within the anticyclone) in the dry phase, whereas ascending motion overlays the negative OLR anomalies (e.g., inside the cyclone) in the wet phase in NVN (Figs. 11a,b). This suggests that boundary layer temperature should be increased immediately (Fig. 12a) because of the effect of air compression associated with the descending motion until the lower troposphere becomes unstable. Physically, the lagged unstable anomaly does not favor the descending motion, but excites ascending motion, and it eventually helps replace the anticyclone with the cyclone (Figs. 4b-e). However, the ascending motion and cyclone cannot persist for a long time either, because the lower troposphere is then stabilized through boundary layer cooling when the regional rainfall anomalies are 
(a) North: Day -10

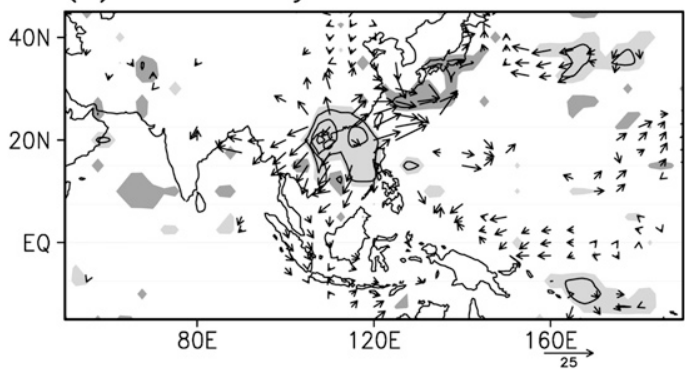

(c) Central: Day -10

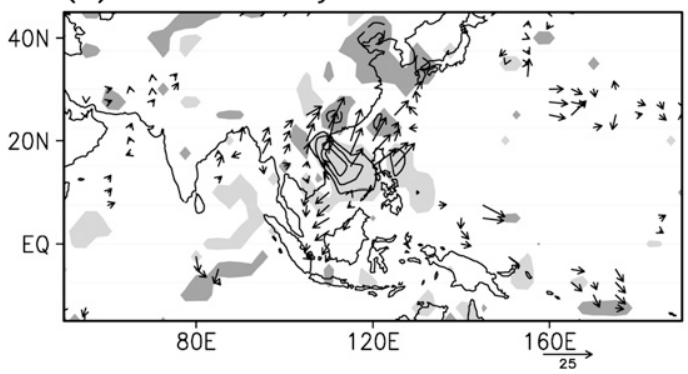

(e) South: Day -10

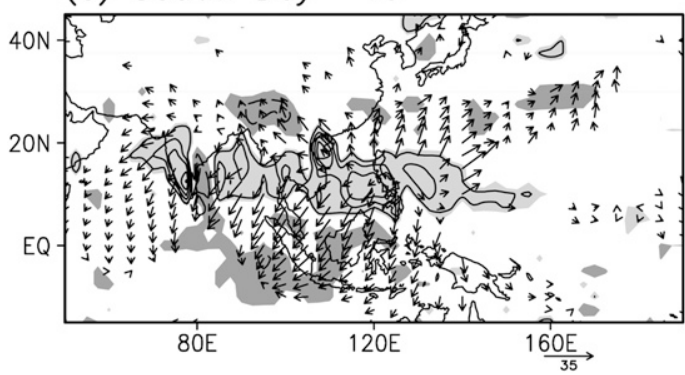

(b) North: Day 10

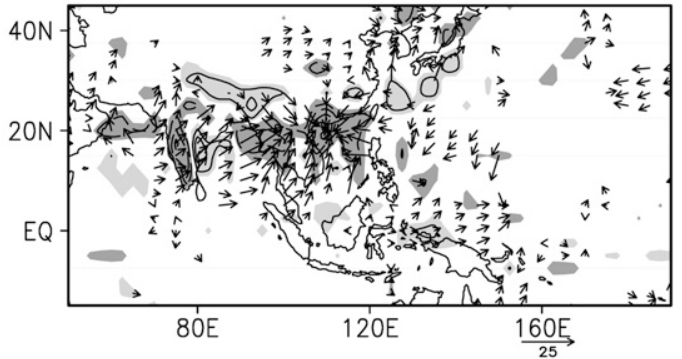

(d) Central: Day 10

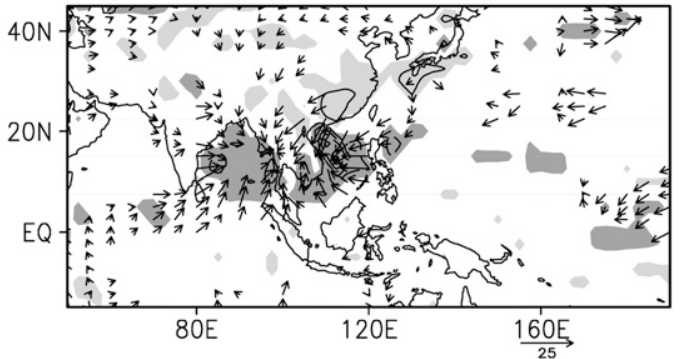

(f) South: Day 10

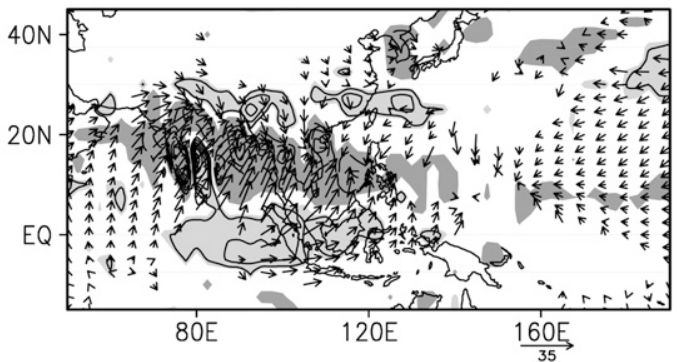

FIG. 11. Divergent component of anomalous moisture flux (vectors; $\mathrm{kg} \mathrm{m}^{-1} \mathrm{~s}^{-1}$ ) and $850-\mathrm{hPa}$ vertical velocity anomalies ( $\mathrm{Pa} \mathrm{s}^{-1}$, contours) at day (left) -10 and (right) +10 associated with the 20-60-day ISO in (a),(b) north, (c),(d) central, and (e),(f) south Vietnam. Solid (dashed) contours indicate positive (negative) values shaded by light (dark) gray. Contour interval is $0.007,0.01$, and $0.005 \mathrm{~Pa} \mathrm{~s}^{-1}$ for north, central, and south Vietnam, respectively. Only $95 \%$ statistically significant anomalies are plotted.

positive (Fig. 12b). In the CVN case, a descending motion generally coincides with the positive OLR anomaly and matures off the CVN coast, where AMF and anomalous winds diverge out, while an ascending motion dominates over the eastern part of China and off the East Asian coast in the dry phase (Fig. 11c). Conversely, the ascending motion attains its maximum development off the CVN coast where AMF converges and the negative OLR anomaly is located in the wet phase (Fig. 11d). At the same time, the descending motion evolves in phase with the stable anomaly over East Asia where $1000-\mathrm{hPa}$ anomalous temperature changes from positive in the dry phase to negative in the wet phase (Figs. 12c,d).

In the SVN case, descending motion is distributed north of the anomalous easterly winds from the AS to the tropical NWP (i.e., within the anticyclonic anomalies) in the dry phase (Fig. 11e), where 1000-hPa temperature anomalies are positive (Fig. 12e) and the lower troposphere later becomes unstable (Figs. 10a-c). Therefore, it may be interpreted that the positive OLR and unstable anomalies are induced primarily by the descending motion, but solar radiative heating of the surface over mainland South and Southeast Asia should be an additional factor. It is clear that the unstable and 1000-hPa temperature anomalies exhibit a much closer correlation than that between destabilization of the lower atmosphere and surface temperature anomalies given by DeMott et al. (2013). The unstable lower troposphere provides favorable preconditions for ascending motion and convection to develop and propagate (Fig. 11f). As expected, the ascending motion dominates where the anomalous OLR is negative and the lower troposphere later becomes stable because of boundary 
(a) North: Day -10

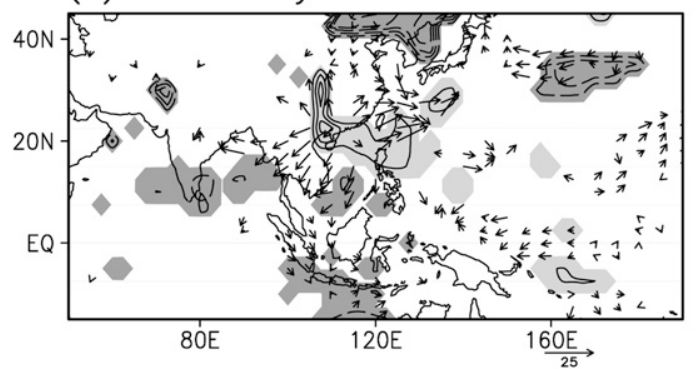

(c) Central: Day -10

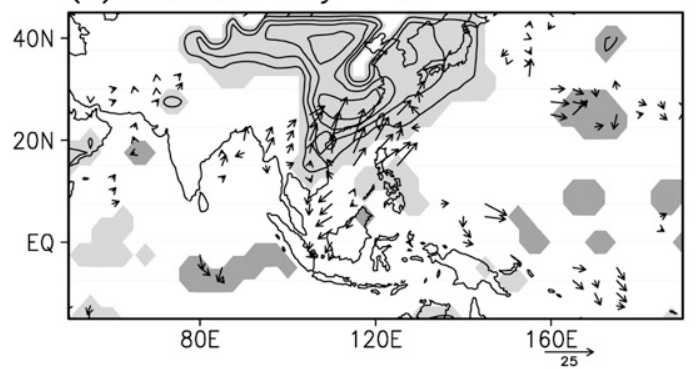

(e) South: Day -10

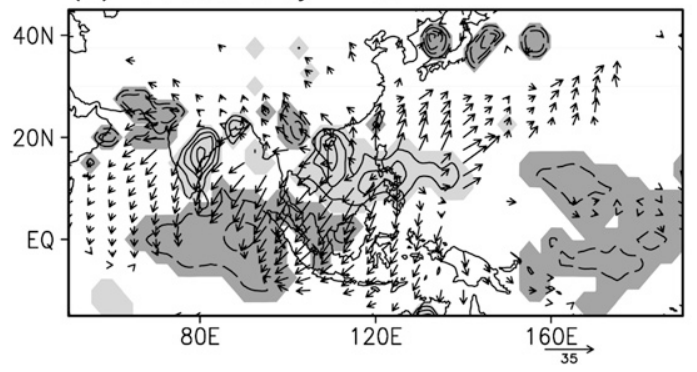

(b) North: Day 10

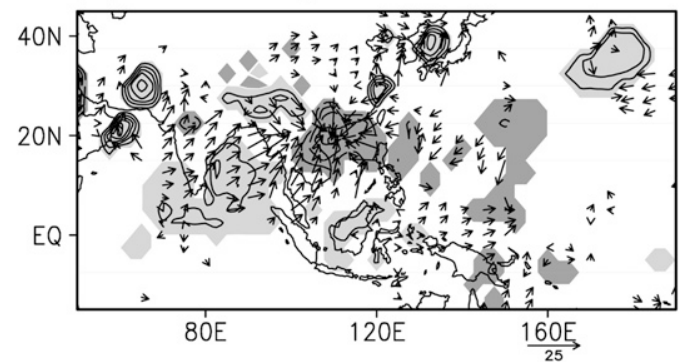

(d) Central: Day 10

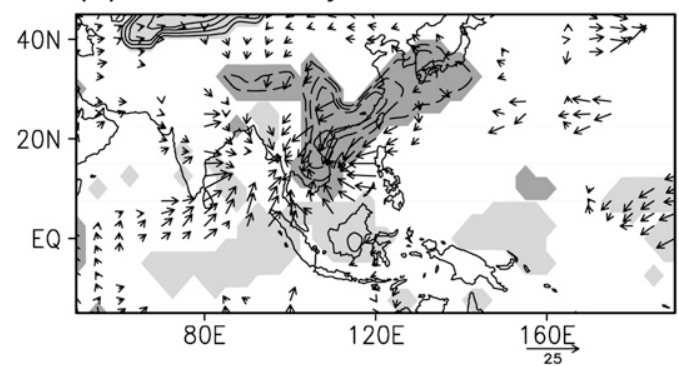

(f) South: Day 10

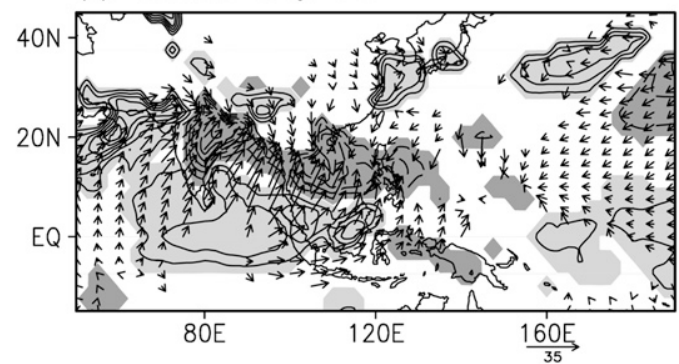

FIG. 12. As in Fig. 11, but for 1000-hPa temperature anomalies (contours). Contour interval is 0.1, 0.2, and 0.075 K for north, central, and south Vietnam, respectively.

layer cooling (Fig. 12f). Similar to conditional stability, the vertical motions are displaced a few degrees of latitude north of the OLR anomalies. Figure 13 demonstrates that $1000-\mathrm{hPa}$ specific humidity anomalies are negative over the divergent areas in the dry phase (Figs. 13a,c,e). This suggests that evaporation from the sea surface is not enough to compensate for the divergence of moisture, despite that the 1000 -hPa temperature anomalies are positive. Conversely, the boundary layer is moistened over the convergent areas in the wet phase (Figs. 13b,d,f). The increase in specific humidity should also be induced by rain evaporation in the boundary layer. It is important to note the appearance of a dry anomaly over East Asia that propagates southward in the CVN wet phase (Fig. 13d).

\section{Vertical cross sections}

The previous section suggests that conditional stability and vertical motions are important factors in understanding the 20-60-day ISOs in Vietnam. To provide further physical insight into their vertical structures, this section presents vertical-longitude sections of specific humidity and vertical pressure velocity anomalies associated with the 20-60-day ISOs in the three regions, which are averaged within $5^{\circ}$ latitude belts (i.e., $7^{\circ}-12^{\circ} \mathrm{N} ; 12^{\circ}-17^{\circ} \mathrm{N}$; and $17^{\circ}-22^{\circ} \mathrm{N}$ ). For convenience, topography is roughly indicated by negative differences between surface pressure and mean sea level pressure in the following figures.

It is evident that an ISO cycle in NVN starts with a dry cell developing between $\sim 100^{\circ}$ and $-130^{\circ} \mathrm{E}$, where descending motion originating near the tropopause is observed to penetrate to the surface (Figs. 14a,b). Anomalous zonal winds are found to diverge out from the dry cell in most of the troposphere that may excite wet cells over the AS and BoB (Figs. 14b,c). The dry cell subsequently disappears in association with the decay of the descending motion and anomalous zonal winds, first to its east and then to its west. The wet phase evolves 
(a) North: Day -10

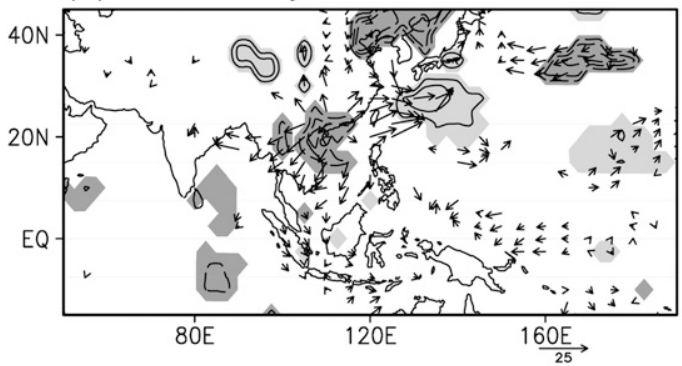

(c) Central: Day -10

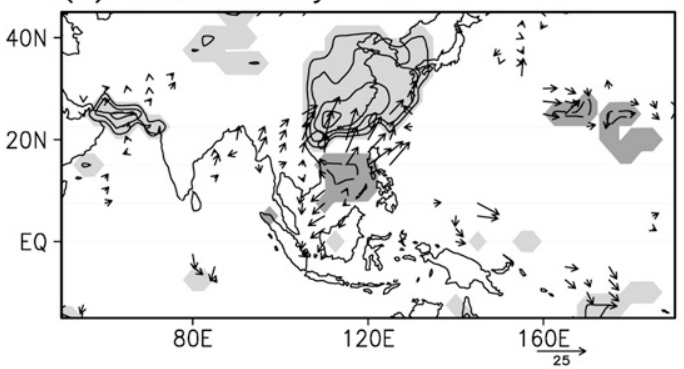

(e) South: Day -10

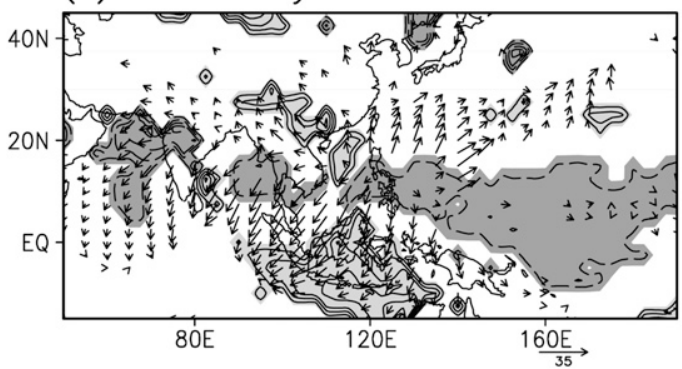

(b) North: Day 10

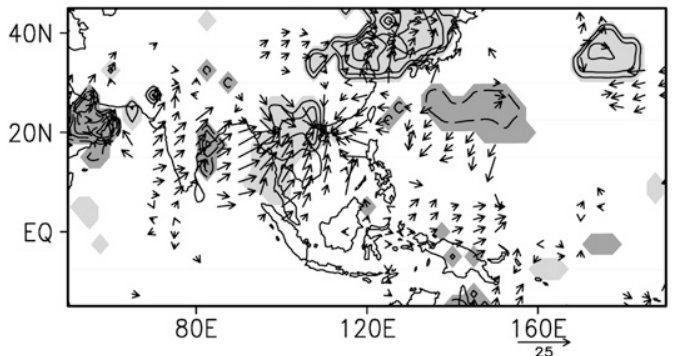

(d) Central: Day 10

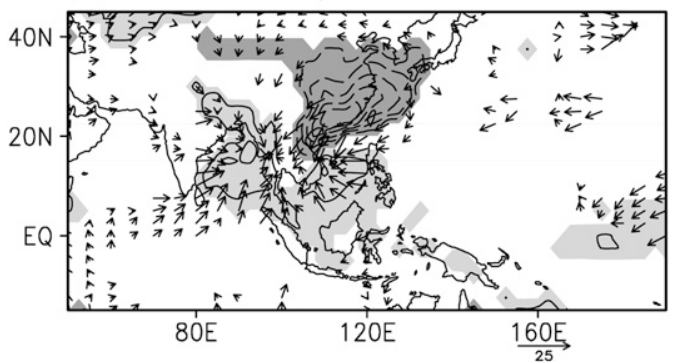

(f) South: Day 10

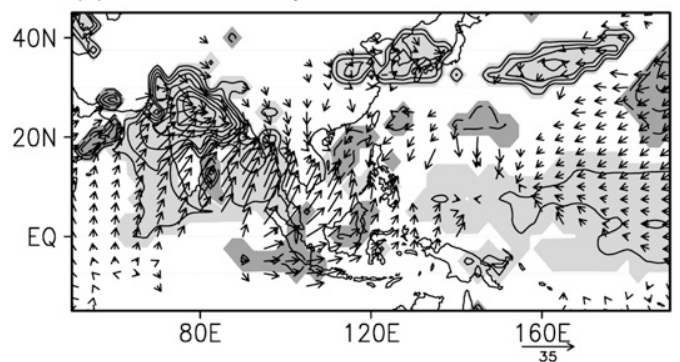

FIG. 13. As in Fig. 11, but for 1000-hPa specific humidity anomalies (contours). Contour interval is 10,15 , and $5 \times$ $10^{-2} \mathrm{~g} \mathrm{~kg}^{-1}$ for north, central, and south Vietnam, respectively.

from a very small wet cell west of $120^{\circ} \mathrm{E}$ in the boundary layer (Fig. 14d), which then grows concurrently with ascending motion and anomalous zonal winds in the troposphere and finally replaces the previous dry cell (Figs. 14e,f). The cell vertical scales are larger than those given by Ajayamohan et al. (2008). Two-sided convergence of the anomalous zonal winds in most of the troposphere is likely to ensure the increase with height of the ascending motion beneath $200 \mathrm{hPa}$. In contrast to the dry phase, dry cells are detected over the AS and BoB shortly after the ascending motion gets most robust in the wet phase (Fig. 14f). The combination of the preexisting conditional instability in the lower troposphere and moisture abundance to higher altitudes is expected to favor outbreaks of deep convection. Generally, the 20-60-day ISO in NVN is stationary and its vertical structure is not tilted with height.

The vertical structure of the 20-60-day ISO in CVN is presented in Fig. 15. Beginning at day -15, a wet cell is observable west of $110^{\circ} \mathrm{E}$ that is in the decaying stage. A dry cell and associated descending motion develop quickly through the whole troposphere to the east of $120^{\circ} \mathrm{E}$, while propagating westward (Fig. 15b). The dry cell splits later into twin cells, of which the eastern cell gradually decays to the east of the Truong Son Mountains (i.e., east of $\sim 107^{\circ} \mathrm{E}$ ), while the western cell continues propagating westward (Figs. 15c,d). It is worth noting the appearance of ascending motion and an accompanying wet cell east of $120^{\circ} \mathrm{E}$ at day 0 , which then evolve rapidly and follow a westward propagation as well (Figs. 15d,e). Similar to the dry cell, the mature wet cell also experiences splitting into twin cells. The right cell is anchored over the eastern slope of the Truong Son Mountains and is then damped out, while the left cell keeps propagating westward across the BoB (Fig. 15f). CVN is totally dominated by strong ascending motion and positive specific humidity anomalies at this time. After day +10 , descending motion appears east of $120^{\circ} \mathrm{E}$ as an incipient signal of the next cycle. The vertical motions are much stronger and the cells do not tilt with 
(a) North: Day -15

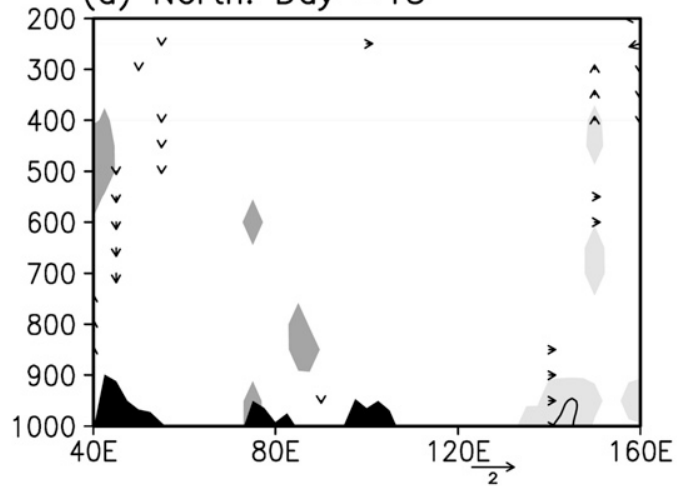

(c) North: Day -5

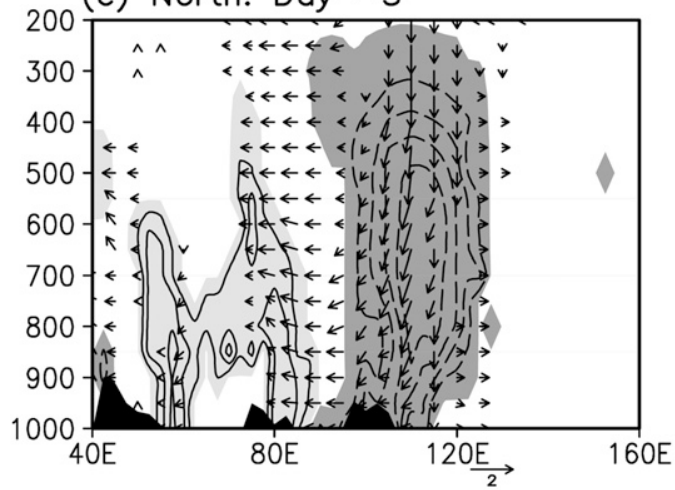

(e) North: Day 5

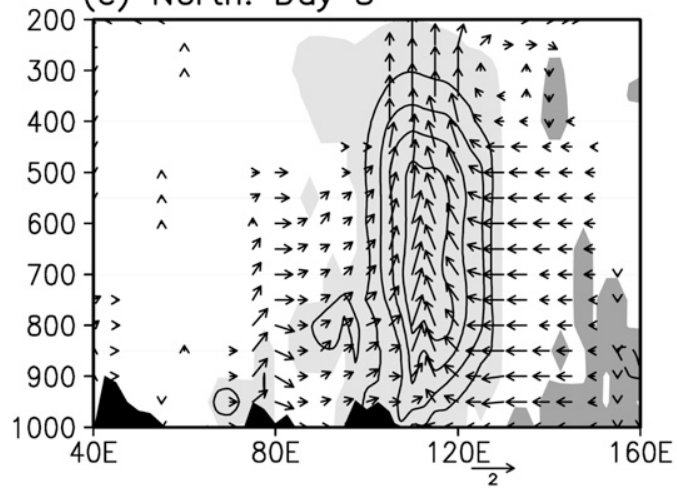

(b) North: Day -10

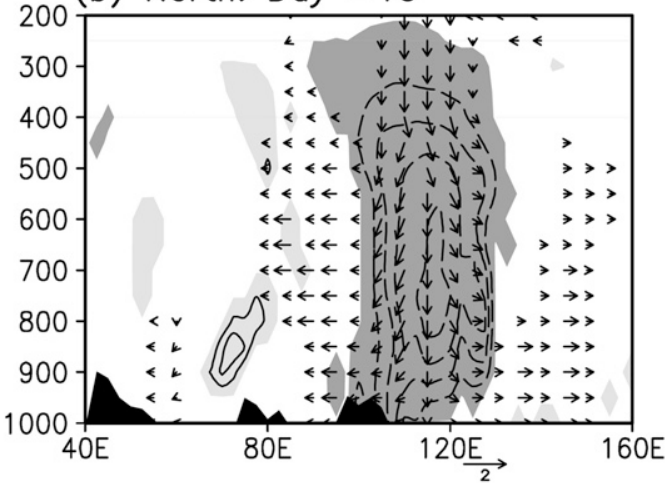

(d) North: Day 0

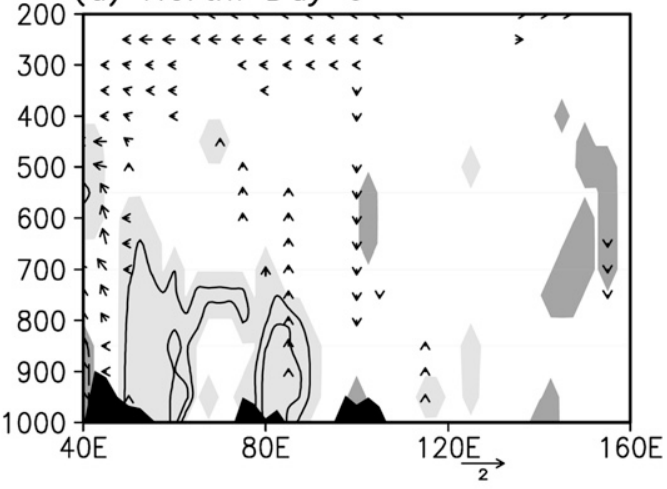

(f) North: Day 10

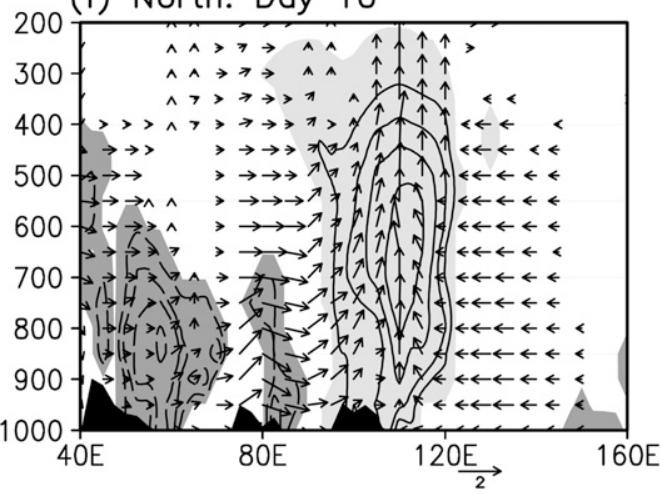

FIG. 14. Composites of vertical-longitude section averaged between $17^{\circ}$ and $-22^{\circ} \mathrm{N}$ of the specific humidity $\left(\mathrm{g} \mathrm{kg}^{-1}\right.$; contours) and wind vector anomalies $\left(u \mathrm{in} \mathrm{m} \mathrm{s}\right.$, and $\omega$ in $\left.-60 \times 1 \mathrm{~Pa} \mathrm{~s}^{-1}\right)$ associated with the 20-60-day ISO in north Vietnam. Solid (dashed) contours indicate positive (negative) values shaded by light (dark) gray. Contour interval is $10 \times 10^{-2} \mathrm{~g} \mathrm{~kg}^{-1}$. Only $95 \%$ statistically significant anomalies are plotted. Black shade indicates topography.

height in this case, compared with those given by Pan et al. (2013).

In the first composite of the 20-60-day ISO in SVN, two dry cells are situated over the NWP and the AS, and a part of the BoB (Fig. 16a). Descending motion then develops dramatically from the tropopause in $\sim 100^{\circ}-140^{\circ} \mathrm{E}$ that is continuously curved rightward and finally spreads horizontally in the form of anomalous easterly winds over the BoB and AS, while penetrating to the surface (Fig. 16b). Concurrently, the right dry cell grows, whereas the left cell gradually decays and is eventually replaced by a wet cell over the BoB and AS (Figs. 16b,c). Such wet cell subsequently extends zonally, makes the dry cell damped out over the NWP, and gives rise to the wet phase in SVN (Fig. 16d). Positive specific humidity anomalies spread across the entire 
(a) Central: Day -15

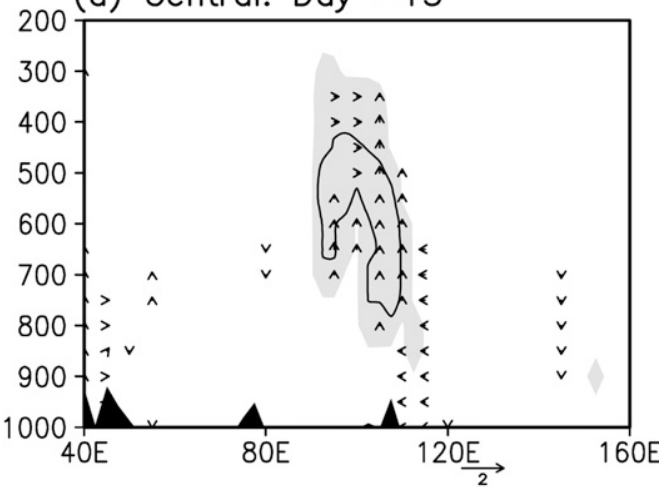

(c) Central: Day -5

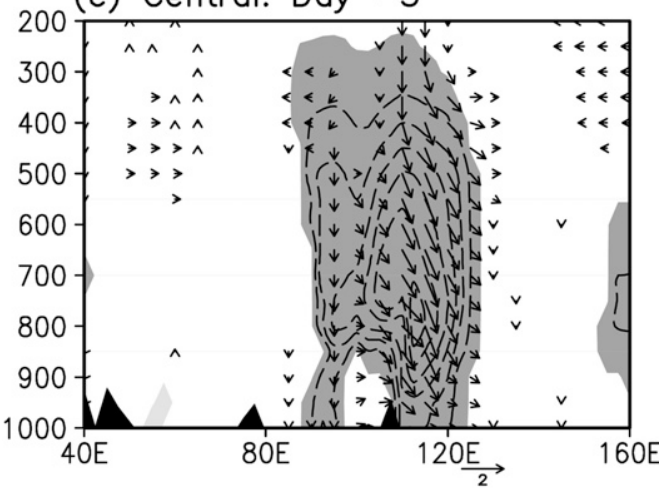

(e) Central: Day 5

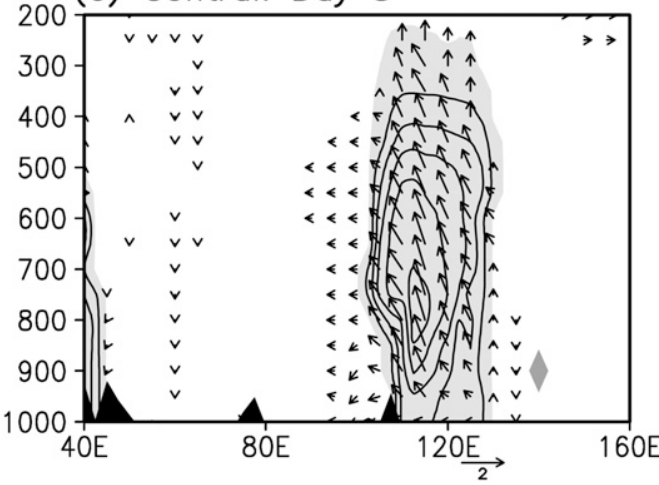

(b) Central: Day -10

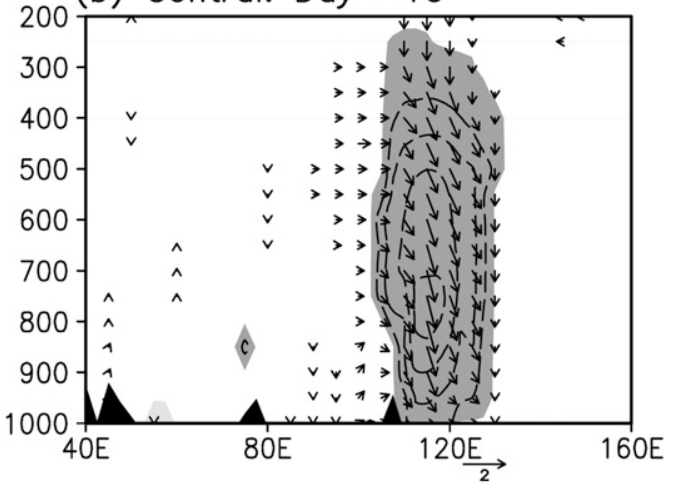

(d) Central: Day 0

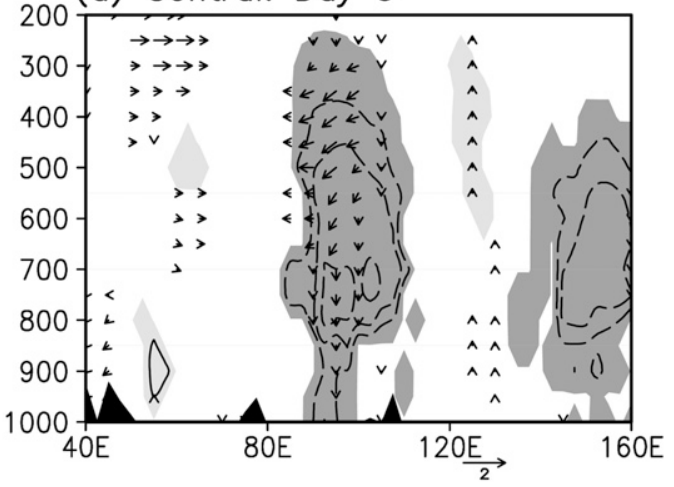

(f) Central: Day 10

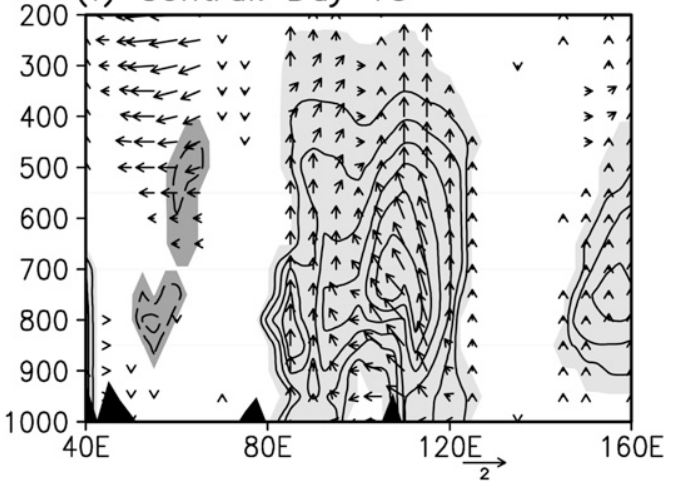

FIG. 15. Composites of vertical-longitude section averaged between $12^{\circ}$ and $-17^{\circ} \mathrm{N}$ of the specific humidity ( $\mathrm{g} \mathrm{kg}^{-1}$; contours) and wind vector anomalies $\left(u\right.$ in m s${ }^{-1}$, and $\omega$ in $\left.-60 \times 1 \mathrm{~Pa} \mathrm{~s}^{-1}\right)$ associated with the 20-60-day ISO in central Vietnam. Solid (dashed) contours indicate positive (negative) values shaded by light (dark) gray. Contour interval is $15 \times 10^{-2} \mathrm{~g} \mathrm{~kg}^{-1}$. Only $95 \%$ statistically significant anomalies are plotted. Black shade indicates topography.

section at day +5 , when the strongest ascending motion is observed at $\sim 100^{\circ}-140^{\circ} \mathrm{E}$ and anomalous easterly (westerly) winds prevail in the lower (upper) troposphere over the tropical NWP (Fig. 16e). A new dry cell is found to originate in the midtroposphere between $\sim 60^{\circ}$ and $-90^{\circ} \mathrm{E}$ at day +10 that seems to initiate a new ISO cycle (Fig. 16f). It is clear that the wet and dry cells are tilted westward with height. As mentioned previously in section 3, the South Asian summer monsoon induces larger vertical shears of the horizontal winds over the tropical IO (also refer to Chou and Hsueh 2010). The present study, however, indicates that BSISO itself possesses vertical shears of the anomalous zonal winds, which are stronger over the tropical NWP than over the tropical IO. These vertical shears are induced by anomalous geopotential heights 

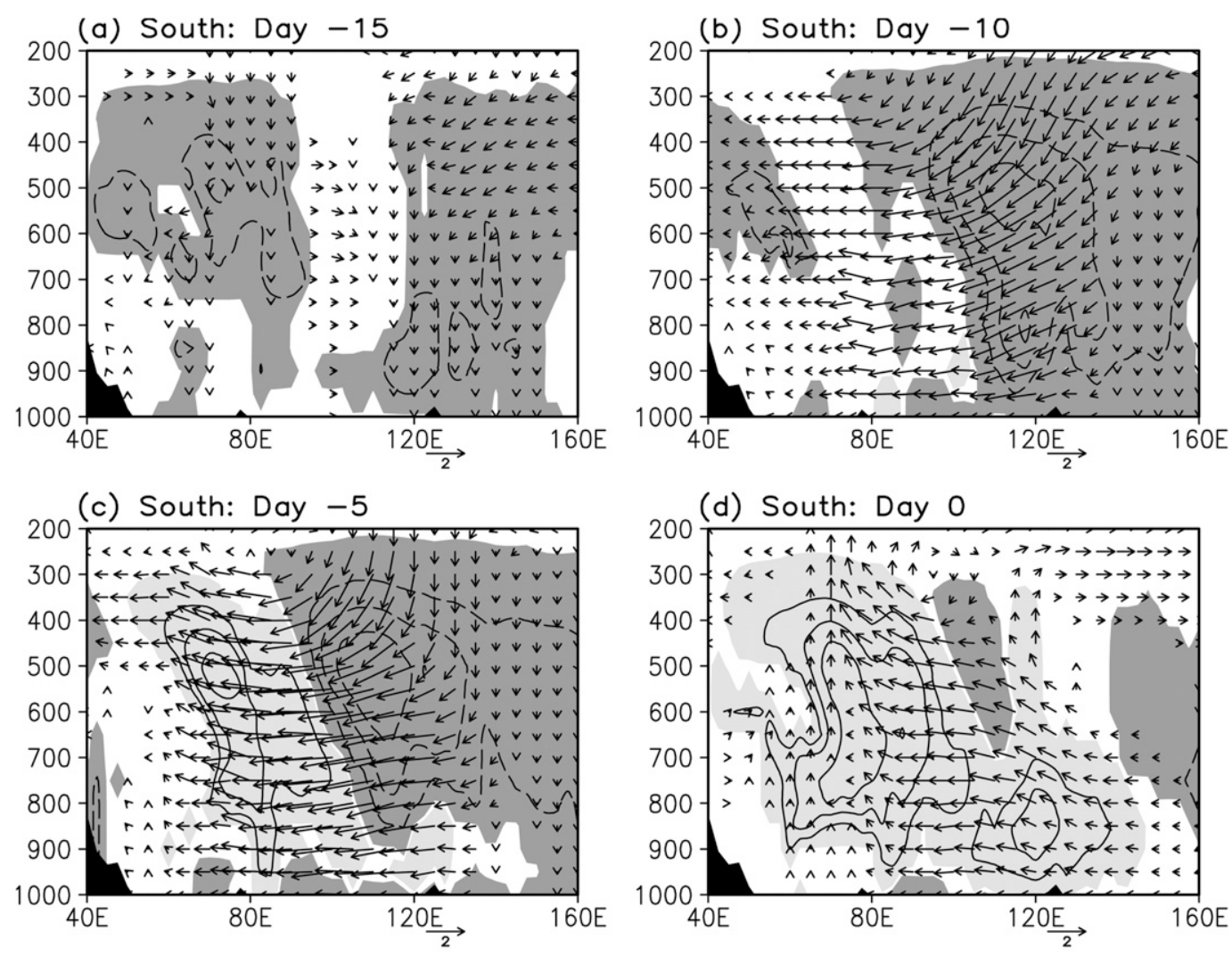

(d) South: Day 0

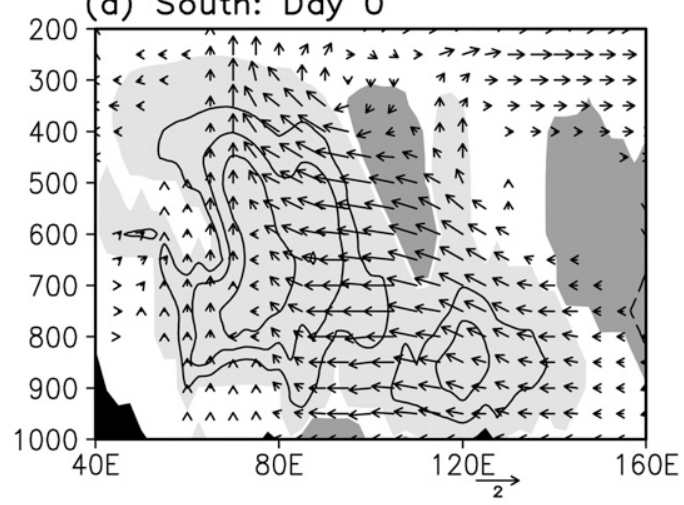

(e) South: Day 5

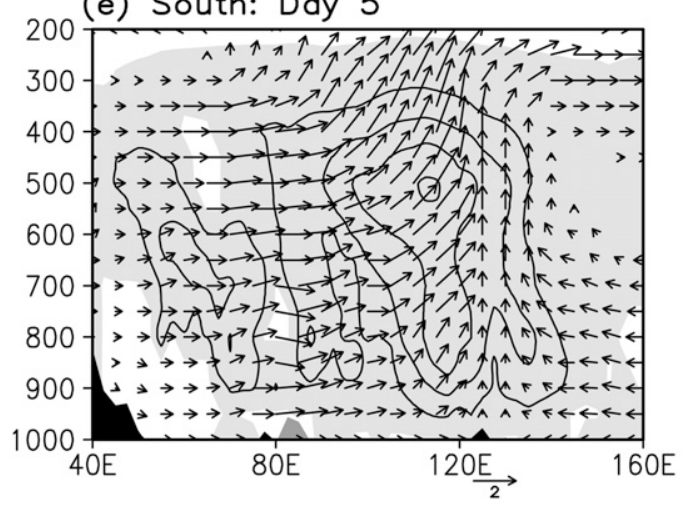

(f) South: Day 10

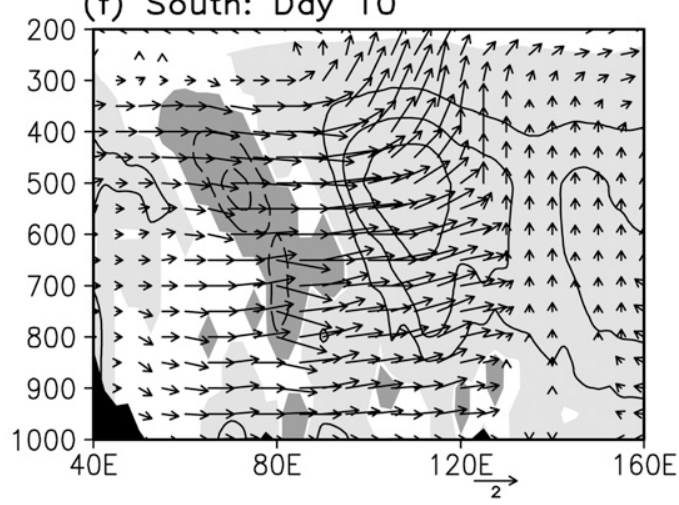

FIG. 16. Composites of vertical-longitude section averaged between $7^{\circ}$ and $-12^{\circ} \mathrm{N}$ of the specific humidity ( $\mathrm{g} \mathrm{kg}^{-1}$; contours) and wind vector anomalies $\left(u\right.$ in m s${ }^{-1}$, and $\omega$ in $-60 \times 1 \mathrm{~Pa} \mathrm{~s}^{-1}$ ) associated with the 20-60-day ISO in south Vietnam. Solid (dashed) contours indicate positive (negative) values shaded by light (dark) gray. Contour interval is $5 \times 10^{-2} \mathrm{~g} \mathrm{~kg}^{-1}$. Only $95 \%$ statistically significant anomalies are plotted. Black shade indicates topography.

over the tropical NWP in the SVN case (Fig. 17c), in which positive geopotential height anomalies are found in the upper troposphere, whereas negative geopotential height anomalies are located in the lower troposphere (Yokoi and Satomura 2005). In contrast, such structure is not observed in the NVN and CVN case (Figs. 17a,b). It may be seen that the wet cells (Figs. 14e, 15e, and 16e) shift a few longitude degrees eastward from the negative geopotential height anomalies (Figs. 17a-c).

\section{Discussion and concluding remarks}

Topography is crucial for the regionality of rainfall climatology in Vietnam because it plays the role of a natural barrier to the Asian summer monsoon. This 
(a) North: Day 5

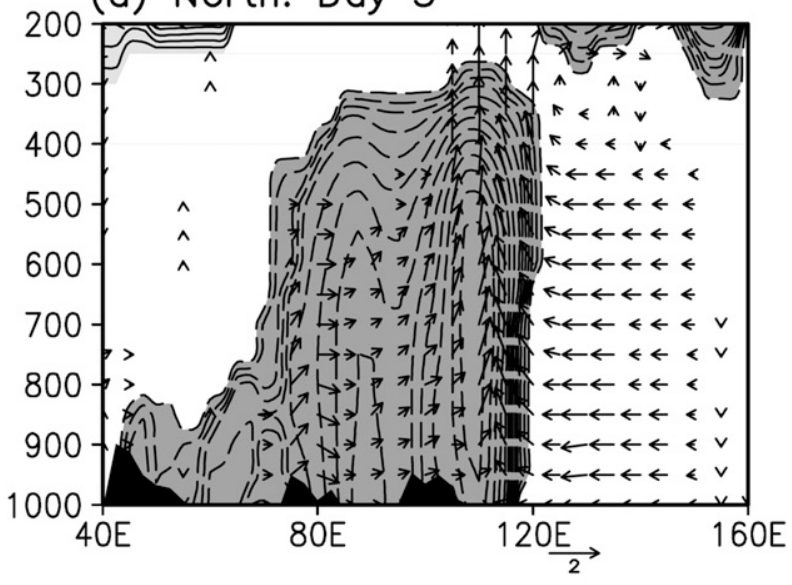

(b) Central: Day 5

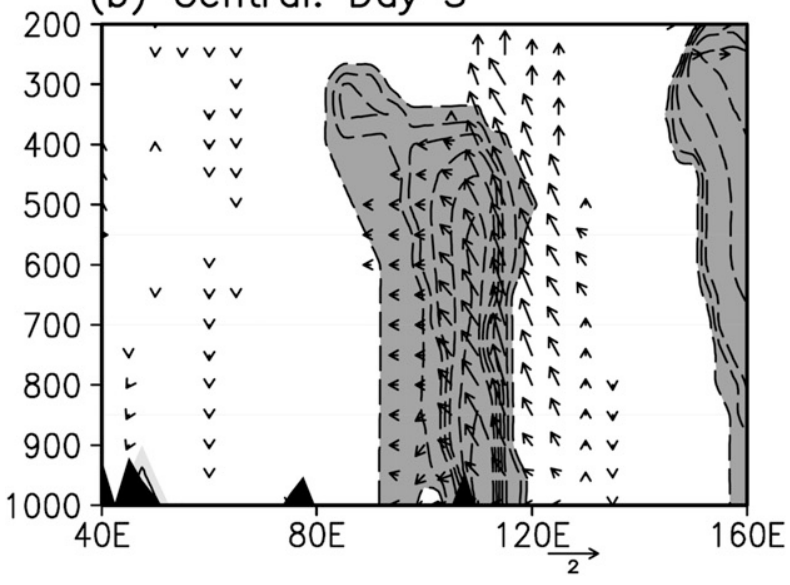

(c) South: Day 5

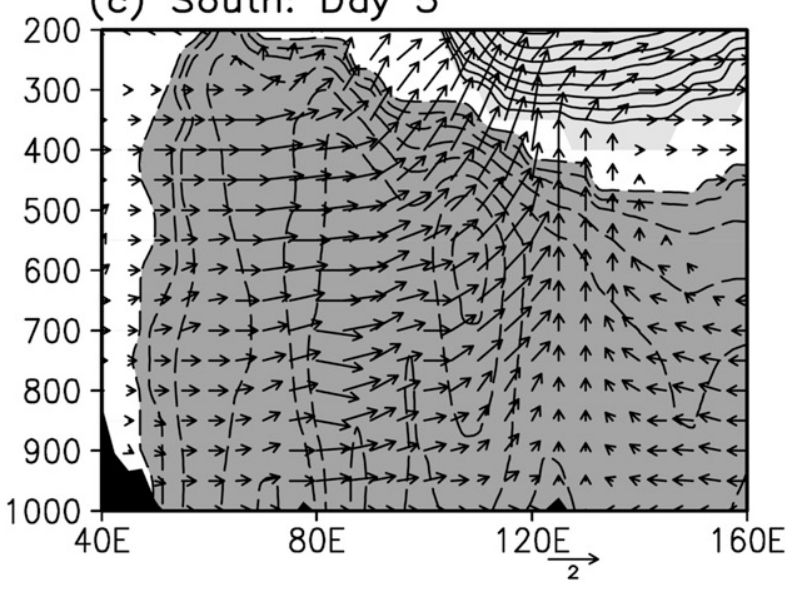

FIG. 17. Vertical-longitude section of the geopotential height (gpm; contours) and wind vector anomalies $\left(u\right.$ in $\mathrm{m} \mathrm{s}^{-1}$, and $\omega$ in $-60 \times 1 \mathrm{~Pa} \mathrm{~s}^{-1}$ ) at day +5 of the 20-60-day ISO in (a) north, (b) central, and (c) south Vietnam. Solid (dashed) contours indicate positive (negative) values shaded by light (dark) gray. Contour interval is $0.5 \mathrm{gpm}$. Only $95 \%$ statistically significant anomalies are plotted. Black shading indicates topography. leads to the delay of the rainy season in CVN until late fall and early winter, whereas summer is the rainy season in NVN and SVN. However, there are significant differences between the 20-60-day ISOs in the latter two regions, though they evolve in a similar seasonal mean environment.

Composite analyses indicate that stationary oscillation of enhanced and suppressed convection determines the 20-60-day ISO in NVN. Specifically, the positive (negative) OLR anomaly, which is confined by the anticyclonic (cyclonic) anomaly, remains located over the Philippines-Vietnam region to govern deficit (excess) of rainfall in the ISO cycle. The existence of the dual vortices straddling Taiwan suggests a tropical-extratropical interaction, or even an interhemispheric interaction, through the large-scale stationary wave structure aligned in the southwest-northeast direction (Mao and Chan 2005; Zhou and Yu 2005). Southward intrusion of the anomalous northerly winds from East Asia combines with the easterly flow from the tropical NWP to create convergence off the CVN coast in the CVN wet phase, while the NWPSH appears to expand in the NWP and the anomalous westerly winds gradually evolve in the tropical IO. This suggests that the 20-60-day ISO in $\mathrm{CVN}$ is governed by both tropical and extratropical factors that influence the whole East Asian summer monsoon system (e.g., Ding and Chan 2005). In the SVN case, the large-scale pattern, anomalies, and their propagation resemble features of BSISO (Chou and Hsueh 2010; Kikuchi et al. 2012; DeMott et al. 2013). That is, the positive (negative) OLR anomalies roughly extend zonally, and they propagate northeastward in association with the development of the anomalous easterly (westerly) winds prevailing south of $20^{\circ} \mathrm{N}$ from the tropical NWP to the AS. The outbreak of convection in the equatorial central IO and its northeastward propagation are responsible for the onset of the wet phase in SVN.

With regard to the mechanisms of the 20-60-day ISOs in Vietnam, the lower troposphere becomes unstable within the anticyclone in the dry phase when AMF diverges, whereas it is stable inside the cyclone in the wet phase in NVN when AMF converges over the region. In a similar fashion, the unstable anomalies are enclosed by the anticyclones from where AMF diverges out in the SVN dry phase, and vice versa. However, the AMF divergence occurs north instead of south of convection maximum in the tropical IO (Chou and Hsueh 2010). Physically, the anticyclones (cyclones) cannot persist for a long time because the unstable (stable) anomalies prevent the descending (ascending) motion within them, which help maintain divergence (convergence) in the lower troposphere, and the dry (wet) phase is finally 
replaced by the wet (dry) phase. In a different manner, it appears that the unstable (stable) air propagates from the Eurasian continent along the northern-eastern rim of the Tibetan Plateau to Vietnam to uniquely determine the dry (wet) phase in CVN, when AMF diverges (converges). Local conditional instability plays no role in producing rainfall in the region.

The AMF divergence ensures clear-sky conditions that favor heating of the surface by solar radiation until the lower troposphere gets destabilized over mainland South and Southeast Asia (Webster 1983; Chou and Hsueh 2010). However, solar radiation is likely insufficient to cause the unstable anomalies over the sea surface. Composite analyses of vertical motions revealed that the descending (ascending) motion occurs in phase and roughly coincides with the positive (negative) OLR anomalies in the dry (wet) phase in NVN and SVN. This implies that the descending motion helps increase boundary layer temperature by air compression to a higher pressure (Wong et al.2011), giving rise to the lagged conditional instability over the tropical oceans. Conversely, the ascending motion produces clouds and precipitation in the wet phase, leading to interception of incoming solar radiation (Chou and Hsueh 2010) and boundary layer cooling by rain evaporation (Wong et al. 2011), and stabilization of the lower troposphere. Note that convective heating near the midtroposphere might also bring to such stabilization (Wong et al. 2011). Not only does the AMF divergence/convergence shift a few latitude degrees north of the BSISO OLR anomalies (Jiang et al. 2004; Chou and Hsueh 2010; DeMott et al. 2013), but the unstable/stable anomalies and vertical motions do the same as well. This leads to the northward propagation of the BSISO convection. The negative OLR anomaly and ascending motion over the CVN region are associated with the southward migration of the stable cold air, which contains low moisture content and descending motion within it, suggesting the arrival of cold air masses (Pan et al. 2013) that often produce torrential rain in the region by forced convection developing over the eastern slope of the Truong Son Mountains (Yokoi and Matsumoto 2008; Yen et al. 2011).

The 20-60-day ISOs in Vietnam are organized in the form of the dry and wet cells, whose heights are about $200 \mathrm{hPa}$, in which the descending and ascending motions are embedded, respectively. Thus, the descending motion is expected to bring drier air from the tropopause to the lower troposphere to generate the dry cells. The cells remain stationary over the $\mathrm{NVN}$ region instead of propagating westward and being split by the Truong Son Mountains as in the CVN case. The ISO in SVN is characterized a westward-tilting structure that is not observed in the other two regions. To investigate the northward propagation of BSISO, previous studies emphasized vertical wind shear over the tropical IO (Jiang et al. 2004; Chou and Hsueh 2010; DeMott et al. 2013). The present study indicates that BSISO itself possesses a large vertical shear of the anomalous zonal winds over the tropical NWP, which may necessitate further studies to clarify, for example, its eastward propagation ( $\mathrm{Li}$ et al. 2013) and regionality in the tropical IO and NWP (Chou and Hsueh 2010; DeMott et al. 2013).

Acknowledgments. This research was funded by the Vietnam National Foundation for Science and Technology Development (NAFOSTED) under Grant 105.06-2015.03. The ECMWF reanalysis data are available at http://apps.ecmwf.int/datasets/data/interim-fulldaily/levtype $=\mathrm{pl} /$. The daily outgoing longwave radiation data were provided by NOAA at http://www.esrl.noaa.gov/ psd/data/gridded/data.interp_OLR.html. The authors declare no conflict of interest.

\section{REFERENCES}

Ajayamohan, R. S., S. A. Rao, and T. Yamagata, 2008: Influence of Indian Ocean dipole on poleward propagation of boreal summer intraseasonal oscillations. J. Climate, 21, 5437-5454, https://doi.org/10.1175/2008JCLI1758.1.

Annamalai, H., and K. R. Sperber, 2005: Regional heat sources and the active and break phases of boreal summer intraseasonal (30-50 day) variability. J. Atmos. Sci., 62, 2726-2748, https:// doi.org/10.1175/JAS3504.1.

Banacos, P. C., and D. M. Schultz, 2005: The use of moisture flux convergence in forecasting convective initiation: Historical and operational perspective. Wea. Forecasting, 20, 351-366, https://doi.org/10.1175/WAF858.1.

Chen, T.-C., J.-D. Tsay, M.-C. Yen, T. T. T. Nguyen, and J. Alpert, 2012: Synoptic development of the Hanoi heavy rainfall event of 30-31 October 2008: Multiple-scale processes. Mon. Wea. Rev., 140, 1219-1240, https://doi.org/10.1175/MWR-D-11-00111.1.

Chou, C., and Y.-C. Hsueh, 2010: Mechanisms of northwardpropagating intraseasonal oscillation-A comparison between the Indian Ocean and the western North Pacific. J. Climate, 23, 6624-6640, https://doi.org/10.1175/2010JCLI3596.1.

Dee, D. P., and Coauthors, 2011: The ERA-Interim reanalysis: Configuration and performance of the data assimilation system. Quart. J. Roy. Meteor. Soc., 137, 553-597, https://doi.org/ 10.1002/qj.828.

DeMott, C. A., C. Stan, and D. A. Randall, 2013: Northward propagation mechanisms of the boreal summer intraseasonal oscillation in the ERA-Interim and SP-CCSM. J. Climate, 26, 1973-1992, https://doi.org/10.1175/JCLI-D-12-00191.1.

Ding, Y., and J. C. Chan, 2005: The East Asian summer monsoon: An overview. Meteor. Atmos. Phys., 89, 117-142, https:// doi.org/10.1007/s00703-005-0125-z.

Drbohlav, H.-K. L., and B. Wang, 2005: Mechanism of the northward propagating intraseasonal oscillation: Insights from a zonally symmetric model. J. Climate, 18, 952-972, https:// doi.org/10.1175/JCLI3306.1. 
Duchon, C. E., 1979: Lanczos filtering in one and two dimensions. J. Appl. Meteor., 18, 1016-1022, https://doi.org/10.1175/15200450(1979)018<1016:LFIOAT > 2.0.CO;2.

Fu, X., B. Wang, T. Li, and J. McCreary, 2003: Coupling between northward-propagating, intraseasonal oscillations and sea surface temperature in the Indian Ocean. J. Atmos. Sci., 60, 1733-1753, https://doi.org/10.1175/1520-0469(2003)060<1733: $\mathrm{CBNIOA}>2.0 . \mathrm{CO} ; 2$.

Fujinami, H., and Coauthors, 2011: Characteristic intraseasonal oscillation of rainfall and its effect on interannual variability over Bangladesh during boreal summer. Int. J. Climatol., 31, 1192-1204, https://doi.org/10.1002/joc.2146.

_ , T. Yasunari, and A. Morimoto, 2014: Dynamics of distinct intraseasonal oscillation in summer monsoon rainfall over the Meghalaya-Bangladesh-western Myanmar region: Covariability between the tropics and mid-latitudes. Climate Dyn., 43, 2147-2166, https://doi.org/10.1007/s00382-0132040-1.

Fukutomi, Y., and T. Yasunari, 2002: Tropical-extratropical interaction associated with the 10-25-day oscillation over the western Pacific during the northern summer. J. Meteor. Soc. Japan, 80, 311-331, https://doi.org/10.2151/jmsj.80.311.

Goswami, B. N., G. Wu, and T. Yasunari, 2006: The annual cycle, intraseasonal oscillations, and roadblock to seasonal predictability of the Asian summer monsoon. J. Climate, 19, 50785099, https://doi.org/10.1175/JCLI3901.1.

Hartmann, B., and G. Wendler, 2005: The significance of the 1976 Pacific climate shift in the climatology of Alaska. J. Climate, 18, 4824-4839, https://doi.org/10.1175/JCLI3532.1.

Holton, J. R., 2004: An Introduction to Dynamic Meteorology. Elsevier Academic Press, 535 pp.

Hsu, H.-H., C.-H. Weng, and C.-H. Wu, 2004: Contrasting characteristics between the northward and eastward propagation of the intraseasonal oscillation during the boreal summer. J. Climate, 17, 727-743, https://doi.org/10.1175/1520-0442(2004)017<0727: CCBTNA $>2.0 . \mathrm{CO} ; 2$.

Jiang, X., T. Li, and B. Wang, 2004: Structures and mechanisms of the northward propagating boreal summer intraseasonal oscillation. J. Climate, 21, 1022-1039, https://doi.org/10.1175/ 1520-0442(2004)017<1022:SAMOTN>2.0.CO;2.

Kajikawa, Y., and T. Yasunari, 2005: Interannual variability of the 10-25- and 30-60-day variation over the South China Sea during boreal summer. Geophys. Res. Lett., 32, L04710, https:// doi.org/10.1029/2004GL021836.

Kang, I.-S., D. Kim, and J.-S. Kug, 2010: Mechanism for northward propagation of boreal summer intraseasonal oscillation: Convective momentum transport. Geophys. Res. Lett., 37, L24804, https://doi.org/10.1029/2010GL045072.

Kemball-Cook, S., and B. Wang, 2001: Equatorial waves and airsea interaction in the boreal summer intraseasonal oscillation. J. Climate, 14, 2923-2942, https://doi.org/10.1175/1520-0442(2001) 014<2923:EWAASI >2.0.CO;2.

Kessler, W. S., M. J. McPhaden, and K. M. Weickmann, 1995: Forcing of intraseasonal Kelvin waves in the equatorial $\mathrm{Pa}$ cific. J. Geophys. Res., 100, 10 613-10631, https://doi.org/ 10.1029/95JC00382.

Kikuchi, K., B. Wang, and Y. Kajikawa, 2012: Bimodal representation of the tropical intraseasonal oscillation. Climate Dyn. 38, 1989-2000, https://doi.org/10.1007/s00382-011-1159-1.

Krishnamurti, T. N., and D. Subrahmanyam, 1982: The 30-50 day mode at $850 \mathrm{mb}$ during MONEX. J. Atmos. Sci., 39, 2088-2095, https://doi.org/10.1175/1520-0469(1982)039<2088: TDMAMD $>2.0 . \mathrm{CO} ; 2$.
Li, K., W. Yu, T. Li, V. S. N. Murty, S. Khokiattiwong, T. R. Adi, and S. Budi, 2013: Structures and mechanisms of the firstbranch northward-propagating intraseasonal oscillation over the tropical Indian Ocean. Climate Dyn., 40, 1707-1720, https://doi.org/10.1007/s00382-012-1492-z.

Liebmann, B., and C. A. Smith, 1996: Description of a complete (interpolated) outgoing longwave radiation dataset. Bull. Amer. Meteor. Soc., 77, 1275-1277, https://doi.org/10.1175/ 1520-0477-77.6.1274.

Madden, R. A., and P. R. Julian, 1972: Description of global-scale circulation cells in the tropics with a 40-50 day period. J. Atmos. Sci., 29, 1109-1123, https://doi.org/10.1175/15200469(1972)029<1109:DOGSCC > 2.0.CO;2.

— and - 1994: Observations of the 40-50-day tropical oscillation: A review. Mon. Wea. Rev., 122, 814-837, https://doi.org/ 10.1175/1520-0493(1994)122<0814:OOTDTO >2.0.CO;2.

Mao, J., and J. C. L. Chan, 2005: Intraseasonal variability of the South China Sea summer monsoon. J. Climate, 18, 2388-2402, https://doi.org/10.1175/JCLI3395.1.

Meehl, G. A., R. Lukas, G. N. Kiladis, K. M. Weickmann, A. J. Matthews, and M. Wheeler, 2001: A conceptual framework for time and space scale interactions in the climate system. Climate Dyn., 17, 753-775, https://doi.org/10.1007/ s003820000143.

, A. Hu, and B. D. Santer, 2009: The mid-1970s climate shift in the Pacific and the relative roles of forced versus inherent decadal variability. J. Climate, 22, 780-792, https://doi.org/ 10.1175/2008JCLI2552.1.

Nguyen, D. N., and T. H. Nguyen, 2004: Climate and Climate Resources in Vietnam (in Vietnamese). Agricultural Publishing House, 296 pp.

Nguyen-Le, D., J. Matsumoto, and T. Ngo-Duc, 2014: Climatological onset date of summer monsoon in Vietnam. Int. J. Climatol., 34, 3237-3250, https://doi.org/10.1002/joc.3908.

Ohsawa, T., T. Hayashi, Y. Mitsuta, and J. Matsumoto, 2000: Intraseasonal variation of monsoon activities associated with the rainfall over Bangladesh during the 1995 summer monsoon season. J. Geophys. Res., 105, 29 445-29459, https://doi.org/ 10.1029/2000JD900499.

Pan, W., J. Mao, and G. Wu, 2013: Characteristics and mechanism of the 10-20-day oscillation of spring rainfall over southern China. J. Climate, 26, 5072-5087, https://doi.org/10.1175/JCLID-12-00618.1.

Pham, X. T., B. Fontaine, and N. Philippon, 2010: Onset of the summer monsoon over the southern Vietnam and its predictability. Theor. Appl. Climatol., 99, 105-113, https://doi.org/ 10.1007/s00704-009-0115-z.

Sohn, B.-J., E. A. Smith, F. R. Robertson, and S.-C. Park, 2004: Derived over-ocean water vapor transports from satellite-retrieved E-P datasets. J. Climate, 17, 1352-1365, https://doi.org/10.1175/ 1520-0442(2004)017<1352:DOWVTF>2.0.CO;2.

Teng, H., and B. Wang, 2003: Interannual variations of the boreal summer intraseasonal oscillation in the Asian-Pacific region. J. Climate, 16, 3572-3584, https://doi.org/10.1175/1520-0442(2003) 016<3572:IVOTBS $>2.0$. CO; 2 .

Truong, N. M., T. T. Tien, R. A. Pielke Sr., C. L. Castro, and G. Leoncini, 2009: A modified Kain-Fritsch scheme and its application for simulation of an extreme precipitation event in Vietnam. Mon. Wea. Rev., 137, 766-789, https://doi.org/ 10.1175/2008MWR2434.1.

Wang, B., and X. Xie, 1997: A model for the boreal summer intraseasonal oscillation. J. Atmos. Sci., 54, 72-86, https://doi.org/ 10.1175/1520-0469(1997)054<0072:AMFTBS >2.0.CO;2. 
Webster, P. J., 1983: Mechanisms of monsoon low-frequency variability: Surface hydrology effects. J. Atmos. Sci., 40, 2110-2124, https://doi.org/10.1175/1520-0469(1983)040<2110: MOMLFV $>2.0 . C O ; 2$.

Wheeler, M. C., and H. H. Hendon, 2004: An all-season realtime multivariate MJO index: Development of an index for monitoring and prediction. Mon. Wea. Rev., 132, 19171932, https://doi.org/10.1175/1520-0493(2004)132<1917: AARMMI $>2.0 . \mathrm{CO} ; 2$.

Wong, S., E. J. Fetzer, B. Tian, B. Lambrigtsen, and H. Ye, 2011: The apparent water vapor sinks and heat sources associated with the intraseasonal oscillation of the Indian summer monsoon. J. Climate, 24, 4466-4479, https://doi.org/10.1175/ 2011JCLI4076.1.

Yasunari, T., 1979: Cloudiness fluctuations associated with the Northern Hemisphere summer monsoon. J. Meteor. Soc. Japan, 57, 227-242, https://doi.org/10.2151/jmsj1965.57.3_227.

_ 1980: A quasi-stationary appearance of 30 to 40 day period in the cloudiness fluctuations during the summer monsoon over India. J. Meteor. Soc. Japan, 58, 225-229, https://doi.org/ 10.2151/jmsj1965.58.3_225.

Yen, M.-C., T.-C. Chen, H.-L. Hu, R.-Y. Tzeng, D. T. Dinh, T. T. T. Nguyen, and C. J. Wong, 2011: Interannual variation of the fall rainfall in central Vietnam. J. Meteor. Soc. Japan, 89A, 259270, https://doi.org/10.2151/jmsj.2011-A16.

Yokoi, S., and T. Satomura, 2005: An observational study of intraseasonal variations over Southeast Asia during the 1998 rainy season. Mon. Wea. Rev., 133, 2091-2104, https://doi.org/ 10.1175/MWR2967.1.

— , and J. Matsumoto, 2008: Collaborative effects of cold surge and tropical depression-type disturbance on heavy rainfall in central Vietnam. Mon. Wea. Rev., 136, 3275-3287, https:// doi.org/10.1175/2008MWR2456.1.

_, T. Satomura, and J. Matsumoto, 2007: Climatological characteristics of the intraseasonal variation of precipitation over the Indochina Peninsula. J. Climate, 20, 5301-5315, https:// doi.org/10.1175/2007JCLI1357.1.

Zhang, C., 2005: Madden-Julian Oscillation. Rev. Geophys., 43, RG2003, https://doi.org/10.1029/2004RG000158.

Zhou, T.-J., and R.-C. Yu, 2005: Atmospheric water vapor transport associated with typical anomalous summer rainfall patterns in China. J. Geophys. Res., 110, D08104, https://doi.org/ 10.1029/2004jd005413.

Zhou, W., and J. C. L. Chan, 2005: Intraseasonal oscillations and the South China Sea summer monsoon onset. Int. J. Climatol., 25, 1585-1609, https://doi.org/10.1002/joc.1209. 